\title{
Inter-Group Relations and Support for Democratization: Evidence from Hong Kong
}

\author{
Tak Huen Chau* Junyan Jiang ${ }^{\dagger}$
}

\begin{abstract}
What drives ordinary citizens to participate in costly pro-democracy endeavors? Conventional theories of democratization emphasize the economic or political conflicts between citizens and elites. This article suggests a different mechanism of mobilization based on intergroup relations. We argue that as a pro-majoritarian institution, democracy may be sought after by members of a disenfranchised majority as a way to protect their interests and identity against perceived economic or political threats posed by certain minority outgroups. We evaluate this argument by drawing evidence from Hong Kong, a city that has recently witnessed major waves of pro-democracy uprisings. Two experimental studies on local university students reveal that subjects' attitudes toward the mainland Chinese visitors and immigrants are causally related to their support for democratization. Observational evidence from surveys and elections further shows that pro-democracy attitudes are stronger in areas that recently experienced a large influx of mainland Chinese. These findings underscore the powerful role of group-based sentiments in episodes of democratization.
\end{abstract}

*PhD Student, Travers Department of Political Science, University of California, Berkeley. Email: thchau@ berkeley.edu

${ }^{\dagger}$ Corresponding Author. Assistant Professor, Department of Political Science, Columbia University. Email: jj3160@columbia.edu 


\section{Introduction}

Active and widespread participation by the mass public has played a crucial role in propelling democratic transitions in many societies. The sight of tens or even hundreds of thousands of people pouring into the streets to challenge an incumbent authority is not only a powerful display of the popular will (Tilly 1978), but also a direct cause of the collapse of many seemingly invincible regimes (Beissinger 2002; Kuran 1991; Linz and Stepan 1996). Yet, for individual citizens, supporting an uprising against the state is an inherently costly action with no guaranteed rewards. What motivates them to engage in such an undertaking?

Existing explanations for popular participation in democratization focus mainly on the conflicts between citizens and the ruling political or economic elites. Prominent theories identify the poor's demand for wealth redistribution (Acemoglu and Robinson 2005; Boix 2003; Collier 2009) and the middle class's struggle for greater rights and freedom (Ansell and Samuels 2014; Huntington 1991; Inglehart and Welzel 2005; Moore 1966) as the two main reasons behind mass democratic uprisings. In this article, however, we argue that pro-democracy mobilization can be built on a much wider range of resentments. Apart from mass-elite conflicts, citizens' grievances against other non-elite actors in a society—even those in relatively mundane forms-can also fuel the mobilization for democratization by reinforcing certain group-based sentiments. Specifically, we argue that members of a politically disenfranchised majority group may seek democracy, a promajoritarian institution, to protect their interests and identity when they face intense competition with a minority outgroup that is perceived to be economically significant or politically threatening. These group-based sentiments can be especially salient in societies that are experiencing large inflows of immigrants or other forms of drastic demographic changes (McNamee and Zhang 2019). They can amplify the existing political and economic grievances that the majority have with the incumbent authority, and act as a powerful emotional force to rally broad-based support for regime change.

We illustrate how inter-group attitudes shape support for democratization by studying Hong Kong, a former British colony that is now a special administrative region of the People's Republic 
of China (PRC). Over the past decade, Hong Kong has witnessed a rising tide of demands for greater democracy (specifically for the adoption of unconditional universal suffrage in selecting the city's chief executive), culminating in an extended series of large-scale protests in 2019-2020. While conventional accounts of the causes of Hong Kong's pro-democracy movement focus on either the city's vast wealth inequality (Veg 2015) or its citizens' fear of losing rights and freedom to an authoritarian national regime (Lee et al. 2019), we argue that another often overlooked factor to explain the movement's widespread popularity lies in the inter-group domain: Since around 2009, a rapidly growing China, coupled with policies pushing for greater mainland-Hong Kong integration, have brought to the city a massive number of mainland visitors and immigrants, who have competed with the local population over limited public resources and economic opportunities. The intense competition has aggravated many local residents' dissatisfaction with the unelected local government, elevated their fear of losing the city's distinct values and life styles, and, consequently, evoked a strong desire to defend their habitat and identity against the unwelcome and potentially assimilating influence from mainland China. These sentiments, as we will argue, have significantly contributed to the rapid rise of pro-democracy activism in the city.

We substantiate this group-based argument with evidence from a series of experimental and observational studies. To shed light on the micro-level causal linkage between inter-group attitude and support for democratization, we conduct two survey experiments on local university students - a group that has been highly active in the city's recent pro-democracy movements. In the first experiment, we use a set of subjective distance questions (Bogardus 1926) to prime a random set of our subjects about their attitudes toward the mainland Chinese before measuring their support for democracy. We find that subjects who harbor strongly negative views of mainlanders will significantly increase both their verbal support for democracy and actual monetary donations to local pro-democracy organizations when their feelings toward the mainland outgroup are experimentally activated through answering the priming questions. This result establishes a causal relationship between outgroup attitudes and support for democratization. In the second experiment, we directly manipulate the extent of perceived outgroup threat by priming subjects with vignettes 
that discuss mainland arrivals of different sizes. We find that subjects' democratic support reacts strongly to the priming treatment that implies a large local presence of the mainland outgroup.

To demonstrate the generalizability of the experimental findings, we also use data from representative surveys and legislative elections to examine how the intensity of real-life exposure to mainland visitors shapes local residents' political attitudes and vote choices. Our observational study takes advantage of the fact that the bulk of the mainland arrivals to Hong Kong come via two border crossings (Lo Wu and Lok Ma Chau), which are connected to the rest of the city through a major railway line. This unique configuration of movement patterns creates variations in mainland visitor presence in different parts of the city, which we exploit for estimation. Our analyses of survey responses show that individuals residing in districts that are more accessible from the two border crossings via public transit tend to report more negative views of mainland visitors, stronger Hong Kong identity, and greater demand for democracy. Analyses of outcomes in Legislative Council elections further reveal that those more mainland-accessible districts have also witnessed a more rapid decline in the electoral performance of pro-regime candidates following the boom of cross-border travel. These findings help to corroborate the experimental results and underscore the relevance of our argument to the city's public at large.

There has been a long-standing scholarly interest in understanding the sources of popular grievances behind major political uprisings, going back as early as Tocqueville's (1856) pioneering study of the French Revolution. Large-scale social movements, however, are inherently difficult to study because they are rare and highly disruptive. Research that probes their internal dynamics often has to be conducted in an ex post fashion, relying on archives, media publications, and personal memoirs to infer participants' motives. However, to the extent that most participants do not leave any traceable record for future researchers, this approach tends to be biased in favor of "master narratives" offered by more vocal elite actors. Our study overcomes this bias by offering a close-up examination of the incentives of actual (and likely) movement participants during an on-going pro-democracy movement. In doing so, we help to shed light on the "assumptions, hopes, needs, longings and interests of ordinary people" (Hobsbawm 1990, p11), and provide a 
more contextualized picture of what mobilized massive outpours of pro-democracy support on the streets of Hong Kong.

\section{Inter-Group Relations and Democratization}

The existing literature offers two perspectives on what motivates citizens to support and take part in pro-democracy movements. The first perspective, drawing on theoretical insights from the canonical model by Meltzer and Richard (1981) and empirical cases from the early democratizing experience of Western Europe, views democratization as essentially a process of class struggle, in which the opportunity to redistribute wealth mobilizes the (relatively poor) mass public to rise up against the wealthy ruling elites (Acemoglu and Robinson 2005; Boix 2003). The second perspective, inspired mainly by cases from the third and fourth waves of democratic transitions, emphasizes the intrinsic values that citizens place on political rights and liberties (Diamond 1999; Inglehart and Welzel 2005). Research that adopts this perspective focuses on either the macro-level structures that facilitate the rise of pro-democracy values (Inglehart and Welzel 2005) or the specific local conditions that enable citizens to effectively coordinate collective actions against a repressive government (Kuran 1991; Lohmann 1994).

While these two perspectives differ in many respects, they nonetheless share a common implicit assumption - namely, that popular support for democratization is driven by grievances directly targeted at the reigning political and economic elites. While mass-elite conflicts are certainly important, we argue that they are not the only reason for citizens to join and fight for a pro-democracy movement. Like many other large-scale social movements, pro-democracy mobilization is a complex, multi-level undertaking that involves participants with a wide range of goals and preferences, not all of which necessarily align with, or are expressed in, the master frame of the movement (Kalyvas 2003). Specifically, we argue that, in some cases, the resentment that leads individuals to want more democracy may actually be rooted in their quotidian interactions with non-elite actors from other competing social groups. 
Our argument builds on a time-honored insight from social psychology that group affiliations are a key aspect of human beings' social life (Turner 1984). Individuals identify with various social groups and derive a sense of belonging and self-esteem from such identification. Group identities play an important role in shaping a person's self-image, her political and social attitudes, and, importantly, how she behaves and interacts with other members of society (Tajfel et al. 1971; Sambanis and Shayo 2013; Shayo 2009). The salience of a given group identity depends on a host of factors, not the least of which is the nature and extent of the competition between different groups (Barth 1969; Sidanius and Pratto 1999; Sherif 1966; Tajfel et al. 1971). Inter-group competition over scarce resources such as territory, wealth, and power strengthens group members' identification with their ingroup and leads them to develop more negative perceptions of the economic and political threats posed by outgroups (LeVine and Campbell 1972; Sherif 1966). These enhanced, group-based sentiments can in turn motivate individuals to engage in collective actions aimed at protecting their ingroup's welfare and outcompeting rival groups (Nielsen 1980; Olzak, Shanahan, and West 1994; Olzak, Shanahan, and McEneaney 1996).

Depending on the context, political actions induced by inter-group competition may take a variety of different forms. When it is the politically dominant group that feels threatened, as in the case of whites in the American South after desegregation, resentment against competing minority outgroups may translate into anti-democratic measures that seek to limit or deny the rights of those minorities (Key 1949; Olzak, Shanahan, and West 1994; Olzak, Shanahan, and McEneaney 1996). However, in situations where the ingroup is large in number but still politically disenfranchised, grievances against a minority outgroup that is perceived to be politically or economically threatening can also propel ingroup members to support greater democracy. Researchers have noted that certain institutional features of democracy may be used to support and justify exclusionary measures. As a system built on the principle of popular sovereignty, for example, democracy typically requires a much clearer definition of who "the people" are than other more hierarchically structured political systems do (Abizadeh 2012; Taylor 1998). Drawing boundaries between those who do and those who do not belong to a political community often inevitably leads to some form of 
differential treatment based on ethnic or cultural group affiliations (Mann 2004; Nodia 1992). The common usage of elections as a mechanism for decision-making also tends to favor large groups over small ones in both symbolic and substantive terms (Przeworski 1999). When inter-group competition is intense, these pro-majoritarian features of democratic institutions may be especially attractive to a politically disenfranchised majority that wishes to defend its rights and interests and redraw the boundaries for who belongs to "the people".

The democratizing experiences of many countries testify to the importance of group-based competition as a driving force. In the United States in the 19th century, for example, many reformers who campaigned for cleaner and fairer elections against urban electoral machines like the Tammany Hall were genuinely worried about the "threat" posed by Catholic and Irish immigrants (Golway 2014). Likewise, leaders of the women's suffrage movement during this period made the case for the urgency of (white) female enfranchisement by framing it as a way to counter the danger associated with granting similar rights first to racial minorities (Cohen 1996). Similar examples can also be found in the more recent second- and third-wave democratization episodes. The discourse of democracy and popular sovereignty, for instance, featured prominently in the nationalist movements of many Asian and African countries during the post-World War II anti-colonial struggles (Emerson 1960). The pro-democracy movement in Taiwan that began in the 1970s similarly drew strength from the cleavage between the majority native Taiwanese and the politically privileged mainland Chinese settlers, who arrived in large numbers with the Kuomintang regime (Yang 2007). Moreover, studies of Estonia and Latvia have shown that ethnic nationalism played a key role in mobilizing popular support for self-determination and democratic transition at the end of the Soviet era (Beissinger 2002; Nodia 1992).

By emphasizing the role of inter-group tension, we are certainly not suggesting that resentment against the elites is irrelevant or unimportant. On the contrary, the two types of sentiments are not only compatible with each other, but also often mutually reinforcing. The majority's anger against an unelected regime may become particularly intense when inter-group competition is fierce and when the regime's policies are seen as disproportionately favoring the minority. In the Baltic 
states, for example, the popular support for democratization and independence was built on both the grievances against the political domination of the Soviet regime and resentment against minority ethnic Russian settlers who occupied affluent jobs in urban areas and lucrative sectors at the expense of the majority Baltic nationals (Dakin 1992; Vetik 1993). In Taiwan, the majority native population's resentment of the minority mainlanders' economic and political privileges also reinforced the majority Taiwanese's view of the Kuomintang administration as a regime imposed by outsiders (Bedford and Hwang 2006). In both cases, democratization was seen as serving the dual goals of toppling a repressive regime and restoring an inter-group balance favorable to the majority group.

\section{Inter-Group Contact, Local Identity, and Hong Kong's Pro-}

\section{Democracy Movements}

As a former British colony, Hong Kong came under the administration of the People's Republic of China (PRC) as a semi-autonomous region in July 1997. Politically, the governance structure of the city between 1997 to 2020 inherited elements from the colonial era: ${ }^{1}$ While political representation remained limited, the residents still enjoyed largely unbridled civil liberties. The Chief Executive is chosen not by popular elections but rather by a selection committee comprised of about 1,200 individuals $^{2}$ representing various sectors and associations. In the legislative branch, moreover, the pro-regime parties have always controlled a majority of seats despite losing the popular vote in every legislative election, due to both the presence of special seats reserved for corporations and professional groups and regular gerrymandering of constituencies held by opposition politicians (Wong 2017).

\footnotetext{
${ }^{1}$ Beijing's imposition of the 'National Security Law' (NSL) in 2020 is alleged of severely curtailing judicial autonomy and civil rights. In the same vein, Beijing's decision to drastically revamp local elections ('patriots ruling Hong Kong') in 2021 is alleged of severely curtailing political rights. This article focuses on the governance structure during the 2019 pro-democracy movement.

${ }^{2}$ The size of the election committee was 1200 in the 2012 and 2017 Chief Executive Elections, and 800 in the 2002 , 2005 and 2007 Chief Executive Elections.
} 
While the pace of change in the political system remained slow after Hong Kong's handover, rapid transformation has occurred in the city's social and economic landscape, especially in terms of the intensity of its cross-border exchange with mainland China. The number of mainland Chinese visiting and migrating to Hong Kong was limited before and during the initial years of the handover, but began to soar after around 2009 because of both a relaxation in travel and immigration policies ${ }^{3}$ and the rising international purchasing power of the Chinese currency (Renminbi, or RMB) following the 2008 Global Financial Crisis. ${ }^{4}$ From 2003 to 2018, the number of collegeeducated mainland immigrants to Hong Kong increased by more than 17-fold, from 1,360 in 2003 to about 25,000 in $2018 .{ }^{5}$ In addition to the skilled immigrants, an even larger group of mainland visitors that began to have significant presence in the city were those who came on short-term tourist visas. Between 2009 and 2014, the annual number of such visitors more than tripled, growing from about 15 million a year to close to 50 million. ${ }^{6}$ Apart from sight-seeing tourism, mainland visitors who come to Hong Kong on tourist visas engage in a variety of non-tourist activities, using the visa to access products and services that are unavailable on the mainland. A significant share of the cross-border trips, for example, are made by parallel traders, who buy large quantities of (imported) cosmetics and daily necessities in Hong Kong and resell them on the mainland. Others have also used the visa to give birth to children with Hong Kong passports, to receive newly developed medical treatments and vaccines, or to purchase financial assets denominated in foreign currencies (Ma 2015).

\footnotetext{
${ }^{3}$ Mainland residents initially needed to apply for an internal visa in order to visit Hong Kong, and tourist visas (for casual visitors) could only be applied for in groups before 2003. A class of special individual-based tourist visas (Individual Visit Scheme, or IVS) were introduced after 2003 to allow mainland residents to visit Hong Kong without having to be affiliated with any official tour groups. In 2009, multiple-visit visas were introduced, allowing mainland citizens to visit Hong Kong for an unlimited number of times with just one visa application. In terms of migration policy, the requirements for skilled mainland immigrants to receive a work visa also became less stringent during this period.

${ }^{4}$ From the end of 2007 and the beginning of 2011, the exchange rate of RMB to US dollar (to which the HK dollar is pegged) rose by about $17 \%$ (data from Chinese Statistical Yearbook)

${ }^{5}$ See, Legislative Council Secretariat, "Secretary of Justice's response to the 2019-2020 budget" (SB053-SB058) Retrieved from https://bit.ly/3a2wKDs

${ }^{6}$ To put this number in perspective: There were 6.8 mainland entries for every local resident in Hong Kong in 2018, while similar figures for New York City and London (counting all international tourists) were 1.61 and 2.3 respectively. Tourism data are available at NYC data (https://www.baruch. cuny. edu/nycdata/Index.html) and London Datastore shorturl . at/ehvD3.
} 
While the rapid growth of mainland immigrants and visitors has brought some new economic opportunities, ${ }^{7}$ it also significantly intensified inter-group competition both in the local labor market and over various essential public goods and private services. As of 2018, there was more than one mainland immigrant with a college degree for every local college graduate, and over $80 \%$ of the junior hire offers in Hong Kong investment banks are now made to mainland Chinese candidates rather than locals. ${ }^{8}$ From 2003 to 2018, the nominal prices of residential and retail space in Hong Kong rose by more than four and six times, respectively, while nominal wages grew by only about 50\% (Li, Cheung, and Han 2018; Wong and Wan 2018). Activities such as birth/medical tourism and parallel trading also caused regular shortages of hospital beds and nursery products such as infant formulas and diapers. ${ }^{9}$ Public transit services also became excessively crowded as a result of the increased number of mainland passengers, and many shops that used to cater to local needs were forced to close, replaced by high-end retailers and pharmacies targeting the mainland clientele (Ma 2015).

In addition to the direct socioeconomic pressure, the influx of mainlanders also feeds into many Hong Kong residents' fears of losing their distinct political identity and culture as a result of demographic changes. Studies have shown, for example, that mainland immigrants to Hong Kong are less likely than the native born to vote for the pro-democracy camp in elections (Wong, Ma, and Lam 2018). As the size of mainland-born voting population grew over the last decade, there were concerns that this would further squeeze the already limited electoral space for prodemocracy parties. Recently, an increasing number of mainland professionals in Hong Kong also started participating in local politics, either by joining the pro-regime parties or by forming new pro-regime parties that compete directly with the existing ones. ${ }^{10}$

As a result of these developments, attitudes toward the mainland Chinese started to grow neg-

\footnotetext{
${ }^{7}$ Studies have found that the economic gains tend to concentrate in only a few sectors (i.e., retail, tourism, and finance) and are captured disproportionately by business conglomerates and property owners (Sung et al. 2015).

${ }^{8}$ See, "Hong Kong Bankers Are Losing Their Jobs to China Rivals", Bloomberg, 12 October 2020. Retrieved from https://bloom.bg/3tbNOhU

${ }^{9}$ See "Price Increase of Infant Formula Milk Higher Than Food Price Inflation Rate", Consumer Council of Hong Kong, March 15, 2011. Retrieved from https://bit.ly/31gBP6j.

${ }^{10}$ See "In Hong Kong, a New Party Calls for Stability (and Raises Suspicions)", New York Times, 16 January 2021. Retrieved from https://nyti.ms/3qtticx
} 
Figure 1: Mainland Visitors and Hong Kong Identity

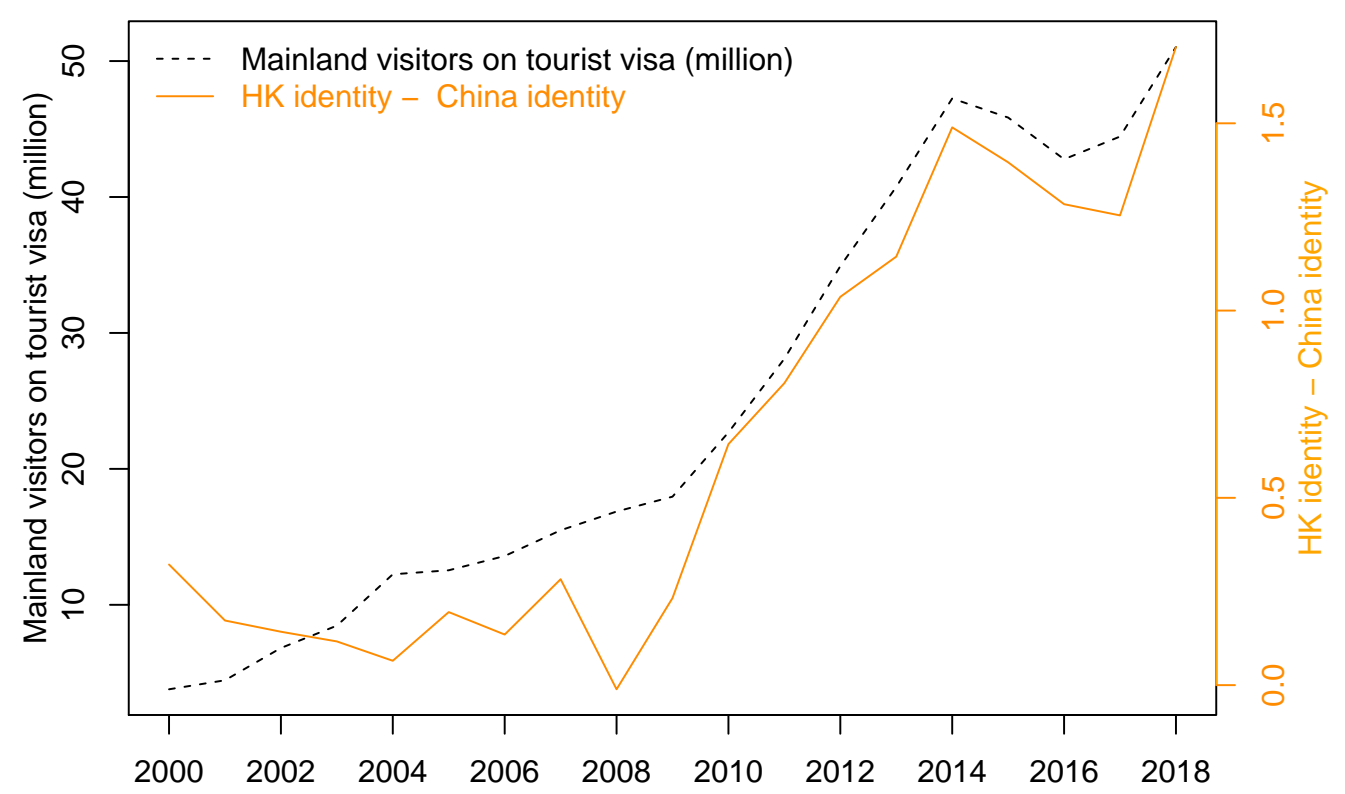

Note: This figure presents the relationship between the number of mainland visitors and the strength of Hong Kong identity between 2000 and 2018. Data on Hong Kong identity are from 46 rounds of representative surveys conducted by Hong Kong Public Opinion Research Institute (averaged to year). The surveys asked respondents how much they identify as a Hong Kong citizen and as a Chinese citizen, respectively. The yellow line plots the strength of the Hong Kong identity minus that of the Chinese identity over time. Data on Chinese tourists are from Statistical Review of Hong Kong Tourism (multiple years).

ative in the city after 2009 , forming the basis of a renewed collective identity for local Hong Kong residents. ${ }^{11}$ As illustrated in Figure 1, while the average Hong Kong resident saw him/herself as a Chinese as much as a Hong Konger before 2009, the relative salience of the Hong Kong identity rose dramatically over the same period when the number of mainland arrivals exploded. The influx of mainland visitors and immigrants fueled local residents' support for democracy in several ways. First, it directly contributed to the dissatisfaction with the incumbent government, which was increasingly seen as a surrogate of Beijing rather than one representing the interests of the Hong Kong people. Moreover, it heightened fears of native-born Hong Kongers being replaced by the mainland-born, who are perceived to be more politically amenable to Beijing. This reinforced

\footnotetext{
${ }^{11}$ Consistent with this trend, a sizable literature has documented that an increase in the size and proximity of an outgroup population can lead to more politicized ingroup identity and worse inter-group relations (e.g., Enos 2015; Forbes 1997; Giles and Buckner 1993).
} 
a popular narrative that universal suffrage was urgently needed in order to have a government that would pay attention to the interests of local residents (Chin 2011). Second, it also created an urge among some local residents to be distinct and separate from the mainland outgroup as well as from mainland China more generally (Ma 2015). According to the literature on social identity, when group identity is salient, individuals tend to place greater importance on norms and attributes that make their own group compare favorably to other outgroups (Tajfel et al. 1971; Turner 1984). To the extent that the difference in political institutions is one of the most visible distinctions between Hong Kong and the mainland, at a time when Hong Kong was perceived as being assimilated into mainland China, those who cared strongly about their Hong Kong identity might become especially keen to preserve and expand the distinction in the political domain (through supporting democratization) and to resist any change that could potentially diminish that distinction.

Beginning in the 2010s, Hong Kong's pro-democracy movement became increasingly intense and featured factions that mobilized on the China-versus-Hong Kong cleavage. It is important to note that while the vast majority of Hong Kong residents have always preferred greater liberty and democracy, participants in pro-democracy movements in the past had typically emphasized and cherished their ethnic Chinese identity. ${ }^{12}$ It is only a very recent phenomenon that a faction of the pro-democracy movement began to express strong anti-mainland sentiments. The localist faction within the pro-democracy camp became a prominent political force over the past decade by capitalizing on public resentment against the growing presence of the mainland Chinese in the city. ${ }^{13}$ In the 2016 legislative elections, the localist faction won over $20 \%$ of the popular vote at the expense of traditional pan-democrats. The localists also played a highly active role in the recent Anti-Extradition Bill Protests, the largest social movement in the city's history. ${ }^{14}$ Scenes

\footnotetext{
${ }^{12}$ During the 1989 Tiananmen protest, for example, pro-democracy activists in Hong Kong organized donations and a fund-raising concert to support student demonstrators in Beijing (Zhao 2004)

${ }^{13}$ In 2012, localist activists organized several high-profile protests against parallel traders in a northern district close to the Hong Kong-mainland border. This event marked the beginning of a series of bottom-up initiatives that sought to push back against the perceived increase in mainland influence, and produced symbols and slogans that became a key part of the repertoire for the subsequent protests. The slogan of the 2012 movement, "Reclaim Sheung Shui Station" (光復上水站), was later adapted to become the first part of the main slogan in the 2019-2020 pro-democracy protest (“Reclaim Hong Kong”光復香港).

${ }^{14}$ One estimate suggests that over $40 \%$ of the city's population engaged in some activities in support of the protest. Young people with some college education were the most active group in the protests, but sympathizers and supporters
} 
of localist protesters attacking companies with mainland background were frequently seen during the the six-month long protest, and some localist supporters professed strong animosity against the mainland Chinese (Lowe and Ortmann 2020). These anecdotal observations aside, there is still limited systematic evidence to how inter-group appeals might have contributed to pro-democracy sentiments and actions. In the pages that follow, we provide to our knowledge the first empirical test on this linkage.

\section{Overview of Empirical Design}

The central hypothesis that follows from the preceding discussion is that reactions against the large influx of mainland Chinese were an important contributing factor to the recent rapid rise in support for democratization among Hong Kong residents. To evaluate this hypothesis empirically, we conduct three inter-related studies. The first two studies, both of which are based on survey experiments on students from a major local university toward the end of the 2019-2020 Anti-Extradition Bill Protests, seek to provide micro-level evidence on whether a person's attitude toward the mainland Chinese outgroup causally affects his/her support for democracy. ${ }^{15}$ In the third study, we further use observational data from multiple years of representative surveys and elections to corroborate and generalize the experimental findings in the city's broader context.

\section{Study 1: Priming Outgroup Attitudes}

\subsection{Subjects and Recruitment}

The goal of our first experiment is to establish that attitudes toward the mainland Chinese are a causally relevant factor in shaping Hong Kong residents' support for democracy. The subjects of

could be found in a broad swath of occupations and socioeconomic strata. See "Seeing Dissent and the Voice of Young People from the Poll Numbers" (in Chinese), Ming Pao, September 27, 2019. Retrieved from https://bit. $1 y / 3 b 3 b r R P$.

${ }^{15}$ It is important to note that all the data that we analyzed in this paper were collected before Beijing's imposition of the NSL, and none of our survey items were considered particularly sensitive at the time of fielding the surveys. We discuss the relevant ethical issues in Appendix A. 
this study are students from a major university in the city. We choose to focus on university students because they have been highly active participants in the recent pro-democracy movement. Close to $80 \%$ of the participants in the 2019-2020 Anti-Extradition Bill Protests held tertiary degrees (Lee et al. 2019), and over $40 \%$ of those arrested during the movement were university students. ${ }^{16}$ Several local universities, including the one where we conducted the study, saw large-scale clashes between the police and the students on campus. An investigation into the mindset of university students can thus offer useful clues about the prevailing sentiments among actual and likely movement participants.

We recruited subjects by sending out university-wide mass emails to the entire student body (both undergraduate and graduate) in March 2020. Students were told that they were invited to participate in a survey on social attitudes, which promised a guaranteed payment of 30 HKD (approximately 3.87 USD) and the chance of winning a lottery of an extra $500 \mathrm{HKD}(\sim 64.5 \mathrm{USD}) .^{17}$ We are primarily interested in responses from local students, who have a direct stake in the movement and comprise the vast majority of the student body. ${ }^{18}$ A total of 607 students $(\sim 3 \%$ of the university's student population) responded to the invitation requests, of whom $94 \%(n=571)$ were local. The subjects that we recruited were broadly representative of the university's student population in terms of the place of origin, gender, cohort, and academic program (see Figure A.1 in Online Appendix). Close to $80 \%$ of the local students reported to have participated in the 20192020 protests when asked, and more than half $(\sim 55 \%)$ reported having witnessed in person violent clashes between protesters and the law enforcement.

\footnotetext{
${ }^{16}$ For arrest figures, see https://bit. 1y/3dBVK42.

${ }^{17}$ For both experimental studies, participation was completely voluntary and subjects' consent was obtained at the beginning of each survey. The pay amount was set according to the local going rate for 30 minutes of work by a student research assistant. Subjects' personal information was collected to verify eligibility and process payments, but was permanently deleted shortly after each study was concluded. We discuss the ethical considerations in Appendix A.

${ }^{18}$ Local students are defined as those who are either Hong Kong permanent residents or admitted to college from local high schools.
} 


\subsection{Experimental Design}

The procedures of the first survey experiment are illustrated in Figure 2. We began the survey with the same set of background questions for every subject and then randomly assigned our subjects into three groups: a treatment group where we primed their attitudes toward the mainland Chinese, a placebo group where we primed their attitudes toward a minority that was not usually seen as a politically significant outgroup (i.e., the disabled), and a control group where no priming was given. We then measured respondents' support for democratic change through a number of attitudinal and behavioral questions. After that, we asked a few additional questions about protest participation and political predispositions before concluding the survey.

Figure 2: Experimental Procedure for Study 1

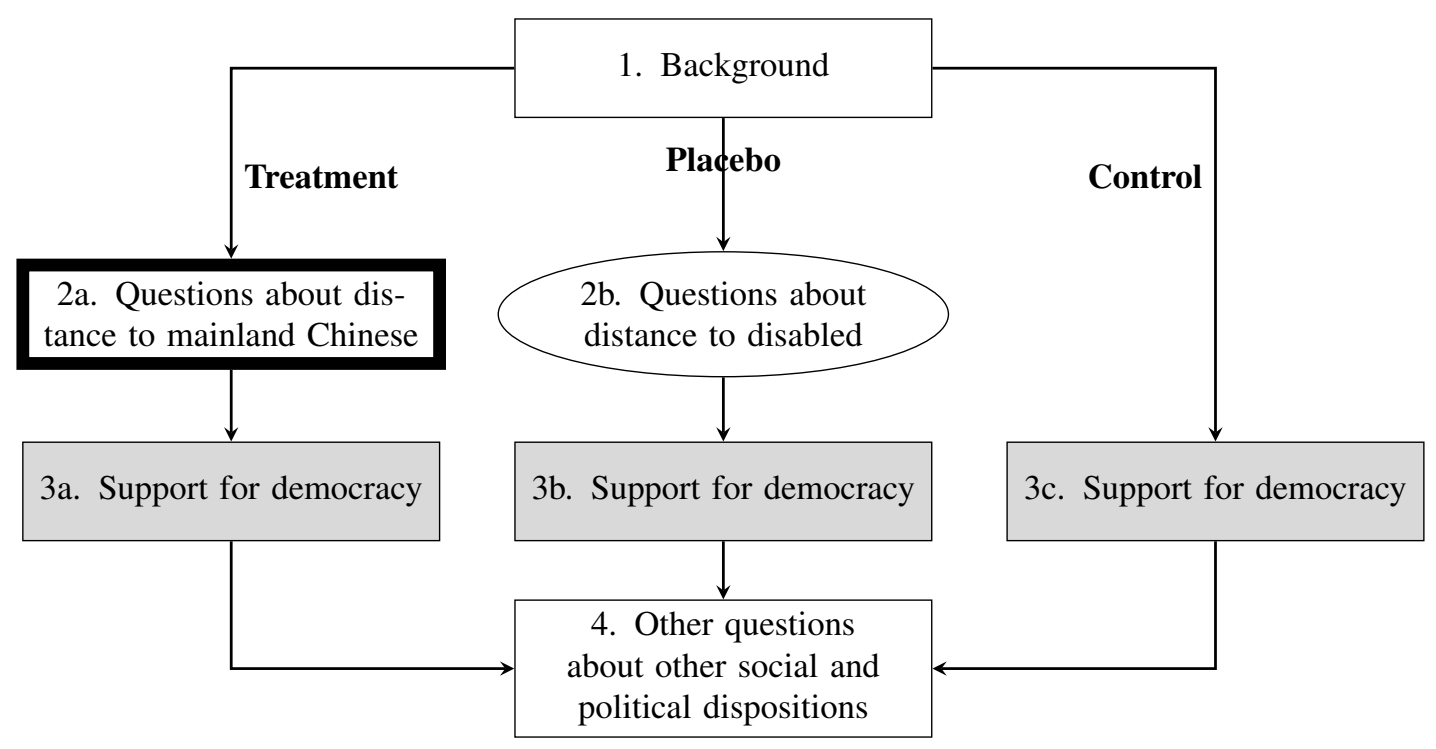

We delivered the priming treatment through a "questions-as-treatment" approach, whereby we first asked our subjects a series of questions about their views of specific outgroups and then examined whether increasing the salience of those groups in their minds would influence their support for democracy. ${ }^{19}$ For the treatment group, we asked a total of six questions in the following format (original traditional Chinese text is in Appendix D):

Treatment Question There are many mainland Chinese in Hong Kong nowadays. How would

\footnotetext{
${ }^{19}$ For other studies using a similar approach, see Bloom, Arikan, and Courtemanche (2015) and Transue (2007).
} 
you feel if they are your [boyfriend or girlfriend] [relatives] [teachers] [roommates] [neighbors] [friends]?

For each question, subjects could choose one of the following answers: (1) not bothered at all (非常不介意); (2) not bothered (不介意); (3) somewhat not bothered (有點不介意); (4) somewhat bothered (有點介意); (5) bothered (介意); (6) very much bothered (非常介意). ${ }^{20}$ Answers with higher numerical values indicate greater aversion to mainland Chinese. Responses to these questions are highly correlated within the same individual, with a reliability score (Cronbach's $\alpha$ ) of 0.92. To simplify the analysis, we applied principal component analysis (PCA) to extract a first dimension from these questions and use it as the main measure of mainland distance.

For subjects in the placebo group, they were given a set of similarly worded questions about their attitudes toward disabled people. ${ }^{21}$ For the placebo and the control group, we also collected information about subjects' reported distance to mainland Chinese at the very end of the survey after they had answered all the key outcome questions and a series of other social and demographic questions. ${ }^{22}$ We did so because the direction and intensity of the question-based treatment is likely to be conditional on a subject's own attitude toward mainlanders. A person who holds strongly negative views toward mainland Chinese may receive a much stronger stimulus from answering the mainland distance question than someone with neutral or even friendly views. Having such information for the two non-treatment groups thus allows us to compare, among individuals who have professed similar attitudes toward mainland Chinese, whether activating outgroup awareness in advance can change their subsequent responses to questions about democratic support.

For our analysis to be valid, one critical assumption is that individuals who exhibit the same level of outgroup aversion in the treatment and non-treatment groups should be comparable in their counterfactual states. This assumption may be violated if subjects change their answers to outgroup attitude questions dramatically when those questions appear in different places of the

\footnotetext{
${ }^{20}$ These questions were adapted from those that measure subjective social distance scales (Bogardus 1925) in social psychology.

${ }^{21}$ The specific wording of the question is, "There are many disabled people in Hong Kong nowadays. How would you feel if they are your [boyfriend or girlfriend] [relatives] [teachers] [roommates] [neighbors] [friends]?"

${ }^{22}$ Specifically, the mainland distance questions were asked in Step 4 of Figure 2 for the control and placebo groups.
} 
survey. When examining responses to those questions across different treatment arms, we notice that they have similar distributions and share a common support. However, the level of expressed aversion does seem to be somewhat higher in the treatment group than in the control and placebo groups (by about $9 \%$ of a SD). ${ }^{23}$ To ensure that the imbalance does not bias our results, we convert the continuous mainland distance variable into a discrete quartile variable based on a subject's relative position within his/her own treatment group. This essentially normalizes the distance score within each group and removes any systematic cross-group differences in responses that may have been caused by our experimental design. We provide a quartile-based balance check for a range of other covariates in Figure A.8, and find the balance to be quite decent.

\subsection{Measurement}

We measured subjects' support for democracy in two ways. First, we asked six questions about their views on the desirability or urgency of achieving democracy. The questions were as follows:

How much do you agree or disagree with the following statements?

1. Democracy is the best form of government despite its shortcomings

2. To get democracy, I am willing to withstand five years of recession, unemployment, and reduced standard of living

3. If possible, I am willing to suspend my study for a year to fight for democracy

4. I am willing to promote democratic ideas in my workplace, even if this may get me fired

5. When necessary, we can use violence against people who speak against democracy

6. Insofar as the goal is democracy, I support spreading rumors and false news to attack the authority

\footnotetext{
${ }^{23}$ One explanation for this difference may be an anchoring effect: In the placebo and control groups, the questions about distance to mainlanders were asked after questions about distance to South Asian and LGBTQ groups, both of which tend to be met with a relatively low level of hostility among the college educated.
} 
Each question have four choices: (1) strongly disagree (非常不同意), (2) somewhat disagree (比較不同意), (3) somewhat agree (比較同意), and (4) strongly agree (非常同意). To the extent that supporting democracy is the general norm among Hong Kong college students, we designed the questions in a way that highlights tradeoffs between democracy and other important priorities or values (e.g., employment, living standards, continuation of college education, commitment to honesty and non-violence). This is intended to capture what/how much a respondents is willing to give up in order to achieve democracy. The Cronbach's $\alpha$ for responses to these questions is 0.73 , suggesting a high degree of internal coherence. To simplify the analysis, we once again extracted the first principal component ( $\sim 47 \%$ of the total variation) from the responses and used it as a summary measure for a person's pro-democracy stance.

In addition to self-reported attitudes, we also constructed a behavior-based measure by giving our subjects the opportunity to make a small but real financial sacrifice in support of pro-democracy causes. Specifically, we told them that they could choose to donate part of their $30-\mathrm{HKD}$ survey payment and 500-HKD lottery (if they win) to any of the following organizations:

\section{DAB (民建聯)}

2. HK Police Welfare Fund (香港警察福利基金)

\section{612 Humanitarian Support Fund (612 人道支援基金)}

\section{Power for Democracy (民主動力)}

\section{Stand News (立場新聞)}

In the context of Hong Kong politics, these organizations carry clear and distinct political connotations. The first two, DAB and HK Police Welfare Fund, are unambiguously pro-government entities, ${ }^{24}$ whereas the other three (612 Fund, Power for Democracy, and Stand News) are organizations affiliated with the pro-democracy camp. ${ }^{25}$ We calculated the total share of payment/lottery

\footnotetext{
${ }^{24} \mathrm{DAB}$ is the largest party in the pro-establishment camp and the HK Police Welfare Fund is a governmentsponsored fund that provides the police force with loans, allowances, and various other fringe benefits.

${ }^{25}$ All three pro-democracy organizations were subsequently shuttered after the imposition of the National Security Law. However, our study took place at a time when they were still active and expressing support for them was legal.
} 
that each respondent chose to donate to the last three organizations, and used it as an indicator for how strongly he/she supports pro-democracy causes. ${ }^{26}$ At the individual level, the amount of donation is highly correlated with reported attitudes: A one standard deviation in pro-democracy attitudes is associated with about a 12 percentage points increase in donation from payment and a 10 percentage points increase in donation from lottery.

Additional information on the experimental design of this study, including summary statistics and covariate balance checks, can be found in Appendix B.

\subsection{Estimation Framework}

We estimate the following heterogeneous treatment effect model:

$$
\begin{aligned}
\text { Democratic support }_{i} & =\sum_{q=1}^{4}\left(\alpha_{q} \text { Mainland distance }_{i}^{q}\right. \\
& +\delta_{q} \text { Mainland distance }_{i}^{q} \times \text { Treatment }_{i} \\
& \left.+\pi_{q} \text { Mainland distance }_{i}^{q} \times \text { Placebo }_{i}\right)+\epsilon_{i},
\end{aligned}
$$

where $i$ indexes individuals. Mainland distance ${ }_{i}^{q}(q \in\{1,2,3,4\})$ is an indicator that takes the value of 1 if respondent $i$ belongs to the qth (within-group) quartile of mainland distance. $\alpha_{q}$ represents the average level of democratic support in mainland distance quartile $q$ for the control group. The key quantity of interest here is $\delta_{q}$, which measures the difference in democratic support between the treatment and the control group within the qth distance quartile. If the argument about inter-group sentiment driving democratic support is correct, our expectation is that $\delta_{q}$ will have positive and significant estimates for higher $q$ s (i.e., the effect is stronger for individuals with greater mainland aversion).

\footnotetext{
${ }^{26}$ A total of 7,299 HKD (941.8 USD) was donated to the three pro-democracy organizations, whereas only 46 HKD (5.9 USD) was donated to the two pro-regime ones. We made actual payments to those organizations according to the wishes of our respondents.
} 


\subsection{Results}

Figure 3 displays the estimated effects for treatment and placebo conditions $\left(\delta_{q}\right.$ and $\left.\pi_{q}\right)$. Each panel represents a questionnaire item, and each yellow (gray) circle represents the mean difference in responses between the treatment (placebo) group and the control group for subjects at a given level of aversion toward mainland Chinese. As expected, we see that the effect of receiving the treatment prime (i.e., questions about attitudes toward mainland Chinese) on democratic support increases progressively with subjects' expressed mainland aversion. While those who harbor no or relatively low aversion against mainlanders show very little change (in some cases, even negative change) in democratic attitudes after receiving the treatment, those who hold strongly negative views about mainlanders significantly increase their support for democracy after answering after being primed about their attitudes toward this group. Focusing on the first panel on overall democratic support, the coefficient estimates suggest that priming attitudes toward mainland Chinese in advance increases expressed support for democracy by about 0.78 units among those whose reported mainland distance belongs to the top $25 \%$ of their respective groups. The effect is not only statistically significant ( $p=0.007$ ) but also substantively large, amounting to almost half of the outcome variable's sample standard deviation ( $\mathrm{SD}=1.58$ ). By contrast, the placebo prime (i.e., questions about attitudes toward the disabled) does not seem to register a similar effect on those with high mainland aversion. The estimated coefficient is weakly negative $\left(\pi_{4}=-0.17, p=0.57\right)$ and statistically different from the actual treatment effect $(p=0.001)$.

The next six panels of Figure 3 present estimates for each of the democratic attitude items. This enables us to examine in greater detail which aspects of our subjects' democratic attitude are most likely to be influenced by the treatment. Interestingly, we find that priming outgroup attitudes does not significantly change respondents' view on the desirability of democracy relative to other systems (Item 1). Instead, the effect seems to be mainly on changing the intensity of preference for democracy, making those with high mainland aversion more willing to shoulder heavy personal costs such as economic recessions (Item 2), suspension of academic study (Item 3), and loss of employment (Item 4). There is also some evidence that priming outgroup attitudes 
increases high-aversion respondents' support for using misinformation to fight the authority (Item 6), but the effect on their support for violence (Item 5) is limited. For Items 2, 3, and 4, the estimated treatment effects are also statistically different from the placebo effects at $95 \%$ level or higher (Table A.1).

The last two panels of Figure 3 (Items 7 and 8) present the effect of outgroup priming on donations. Item 7 is based on donations from the 30-HKD payment (which they would get for certain) and Item 8 is based on donations from a possible 500-HKD lottery win. Consistent with what we find for attitudes, we see that, for both types of donations, the effect of priming mainland attitude increases monotonically as respondents' mainland aversion increases. In particular, for those who belong to the top quartile of mainland aversion, the treatment prime results in a 19 percentage points increase in payment donations compared to the control group $(5.7 \mathrm{HKD}, p=$ 0.045 ) and a 14 percentage points (or $70 \mathrm{HKD}, p=0.083$ ) increase in lottery donations. The estimated effects are very similar when we use the placebo group as the benchmark (Table A.1). Taken together, these results suggest that, for the subset of individuals who harbor intense aversion toward the mainland outgroup, activating such aversion can substantially increase their support for pro-democracy struggles.

We conducted a series of additional tests to ensure the robustness of our findings. To check whether our results are driven by the specific way we constructed the moderating variable, we re-estimated the baseline regressions with several alternative measures of distance to mainlanders. These alternative models yield very similar results (Tables A.2, A.3, and A.4). In addition, we also tried to control for a host of pre-treatment covariates on respondents' demographic, academic, and family background (as well as their interactions with the treatment indicator). The main results remain largely unchanged with these additional controls (Table A.5). The details of the robustness results can be found in Online Appendix C. 


\section{Figure 3: Baseline Results}

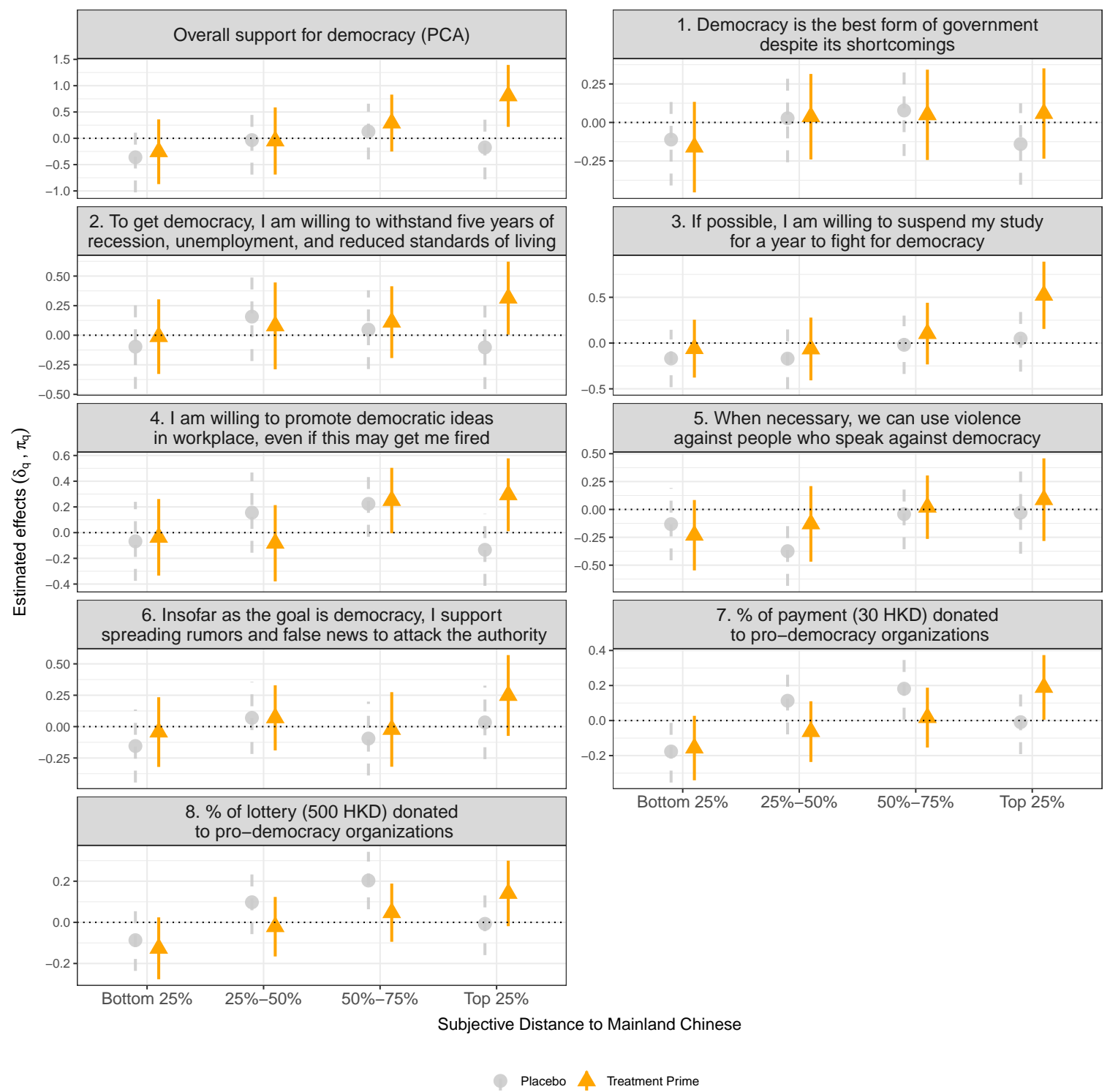

Note: This figure presents estimated treatment and placebo effects from the first experiment. Each yellow (gray) circle represents the mean difference in responses between the treatment (placebo) group and the control group for subjects at a given level of mainland Chinese aversion, and the vertical lines represent $95 \%$ confidence intervals. The numerical regression results for the top quartile are reported in Table A.1 of Online Appendix. 


\section{Study 2: Manipulating Outgroup Threat}

\subsection{Design}

The results from Study 1 suggest that our student subjects' support for democracy is causally influenced by their attitudes toward the mainland Chinese outgroup. However, it is still unclear what specific considerations were being activated when these sentiments were translated into democratic support. To address this issue, we conducted a second study in which we experimentally manipulated subjects' outgroup attitudes and examined the effectiveness of such manipulations in changing their support for democracy. The follow-up study was fielded at the same university three months after the first study, and subjects were recruited using the same method of mass email. ${ }^{27}$

The procedure for the second study is illustrated in Figure 4. Like the first study, we began the survey with a battery of background questions and then randomly assigned survey respondents into three groups: one control group and two treatment groups (Group A and Group B). In both treatment groups, we first asked respondents to estimate a specific statistic/quantity that could be interpreted as reflecting the scale of the mainland influx, and then provided the respondents with the actual figure. We deliberately chose quantities for which the actual figures tend to be more extreme than the popular belief (either much higher or lower). The expectation is that the combined experience of making a guess of the size of the mainland influx and receiving a relatively extreme figure as the answer will either elevate or ameliorate (depending on the context) our subjects' perceptions of the threat posed by the mainland outgroup and subsequently influence their support for democratization. ${ }^{28}$

For Group A, we tried to increase the perceived threat from the mainland outgroup by first asking subjects to estimate how many mainland Chinese visited Hong Kong on tourist visas each year and then presenting the actual number (51 million) along with a brief mention of several

\footnotetext{
${ }^{27}$ About $25.6 \%$ of the subjects recruited also participated in the previous study. All our results hold when excluding this subset of respondents (see Table A.7). We did not include the donation questions in this round due to budget restrictions from the funding source.

${ }^{28}$ For a similar approach, see Huang (2015). As shown in Figure A.10, the vast majority of the responses tend to either underestimate or overestimate the quantities of interest, and the biases are all in the expected directions.
} 
Figure 4: Experimental Procedure for Study 2

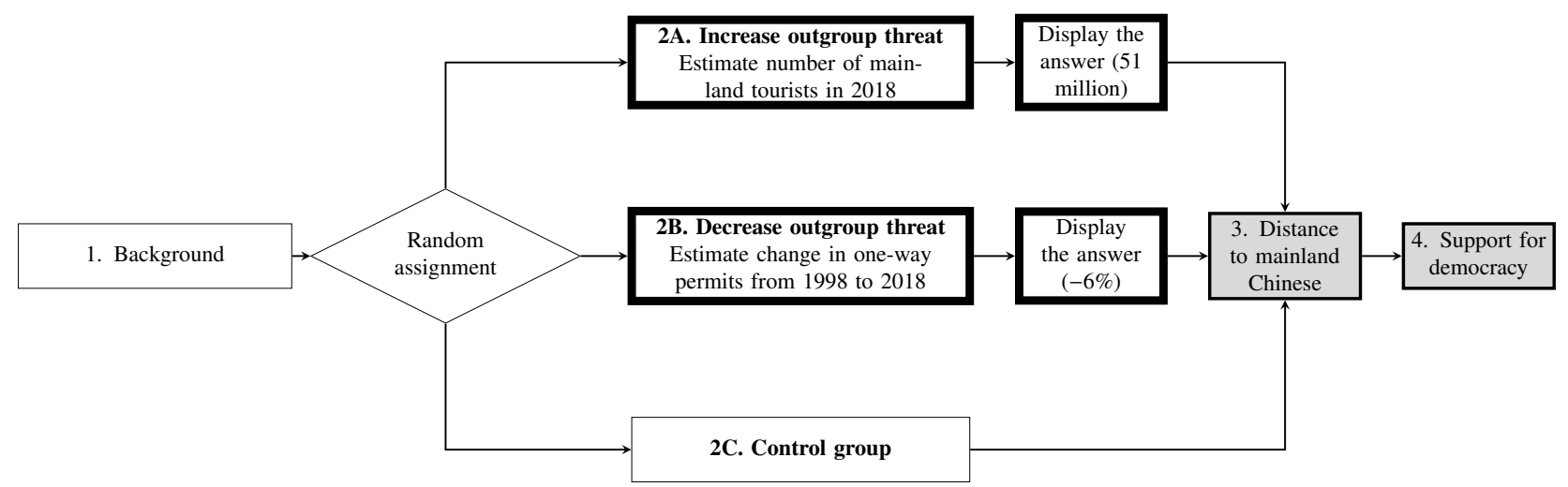

types of visitors that are particularly disruptive to local residents' livelihoods (e.g., parallel traders, property speculators, and parents who engage in birth-tourism). In Group B, by contrast, we tried to decrease the outgroup threat by asking respondents to guess the rate of change in the arrival of one-way permit holders (i.e., mainland immigrants coming for family reunification). While the number of skilled visa holders coming from the mainland increased exponentially, the number of people coming on one-way permits has been steadily decreasing since the handover. We provided this information to respondents after they gave their estimates, with the expectation that it would assuage their worry about the mainland influx. The vast majority of our subjects underestimated the number of mainland tourists and overestimated the rate of change in one-way permit arrivals (Figure A.10). Appendix E provides the detailed question wording and comparisons between respondents' guesses and the actual figures for both treatments.

\subsection{Results}

The results from the second experiment are displayed in Figure 5. The sub-graph on the left shows the estimated effects of the two treatments on outgroup attitudes, and the one on the right shows the treatment effects on support for democracy. Here, we clearly see that the tourist treatment has a visible effect on both outgroup aversion and democratic support. Compared to the control group, the group that learned about the large annual influx of mainland visitors reported significantly greater distance to members of the mainland outgroup $(16 \%$ of an SD, $p<0.001)$ and stronger support 
for democracy ( $11 \%$ of an $\mathrm{SD}, p=0.02)$. A mediation analysis following the procedures recommended by Imai et al. (2011) suggests that about $41.5 \%$ of this treatment's effect on democratic support is mediated by increased mainland aversion. ${ }^{29}$ This result provides further confirmation that ingroup members' support for democracy responds to experimentally induced variations in outgroup attitudes. Interestingly, the one-way permit holder treatment does not appear to have any significant influence on subjects' expressed attitudes for either the mainland outgroup or democracy, which might suggest that the attitudinal impacts of increasing and reducing the perceived outgroup threat are asymmetric.

Figure 5: Experimental Results from Manipulating Outgroup Threat
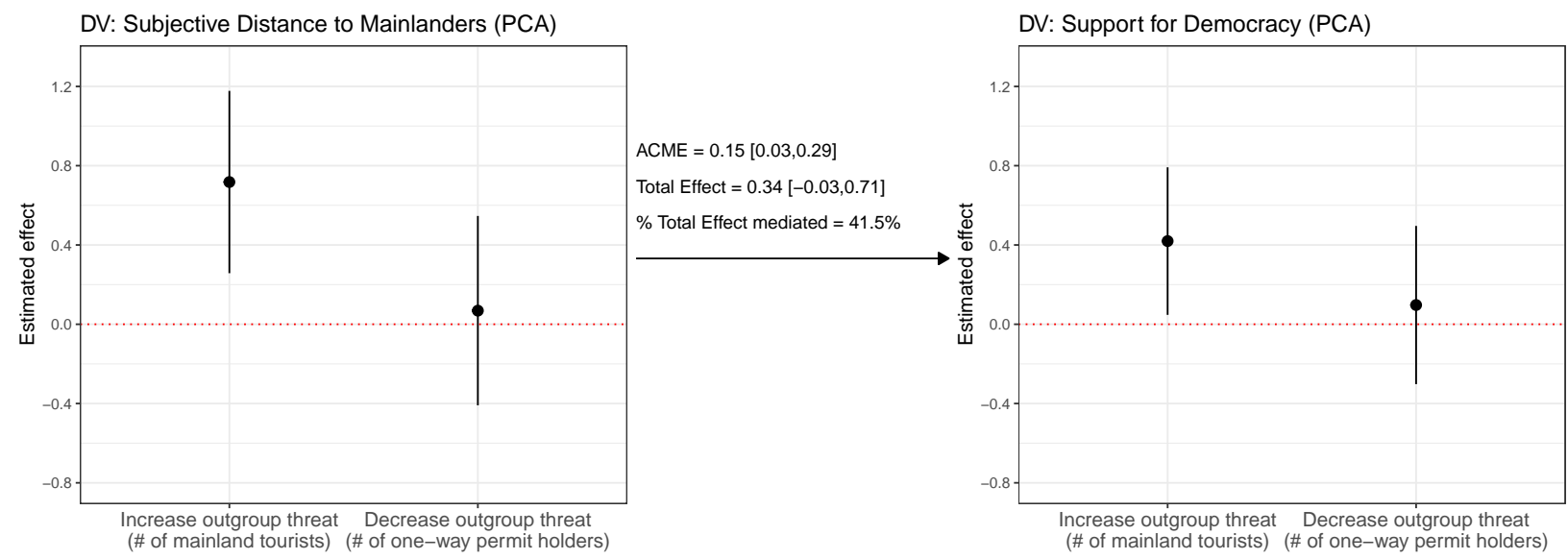

Note: This figure presents estimated effects of the two treatments (relative to the control group) on mainland distance and democratic support from Study 2. The circles represent point estimates and the vertical lines $95 \%$ confidence intervals. The numerical results are reported in Column 1 of Table A.6. ACME = average causal mediation effect

\section{Corroborating Observational Evidence}

The results from the experimental studies demonstrate that, within our sample of local Hong Kong university students, (1) one's attitude toward mainland Chinese causally influences his/her attitude toward democracy and (2) priming students about the large size of the mainland influx can lead

\footnotetext{
${ }^{29}$ As a manipulation check, we also asked subjects questions about their views on immigration policy after delivering the treatment. Subjects in this group (outgroup threat + ) were significantly more likely to support restricting immigration than those in the outgroup threat + group. Results are available upon request.
} 
to a measurable increase in both their outgroup aversion and democratic support. While these patterns seem consistent with our argument, an important question that remains is whether the experimental findings can be generalized beyond university students. To address this question, we provide additional corroborating evidence from observational studies using representative surveys and election data.

Our observational studies leverage the spatial variation in exposure to mainland visitors within Hong Kong. A unique fact about the cross-border population movement between Hong Kong and mainland China is that the bulk of the mainland visitors to Hong Kong ( $\sim 60 \%)$ come through two customs checkpoints: Lo Wu and Lok Ma Chau. ${ }^{30}$ Both checkpoints are located at the northern end of Hong Kong and are connected to the rest of the city by the East Rail Line (ERL), the only cross-border metro line. Given this spatial layout, many mainland visitors who enter Hong Kong via these checkpoints often choose to dwell in areas close to the border or accessible through the ERL because of convenience and low travel cost. Compared to those in more distant areas, local residents living in the checkpoint region or ERL-accessible areas will therefore have more frequent encounters with mainland visitors, and may consequently develop more negative outgroup attitudes and stronger desire for democracy.

Using proximity to ERL as a measure for mainland visitor presence, we examine several outcomes. In the interest of space, we mainly present visual illustrations here and leave the detailed regression analyses to the Appendix (Section F.4). First, to verify that proximity to ERL is a reasonable proxy for the size of mainland arrivals, we collect and plot data on the over time change in the number of retail shops selling medicines and cosmetics, which are highly sought-after products among mainland tourists and parallel traders. ${ }^{31}$ To cater to this large customer base, many retail shops that opened over the past decade were in locations with a high concentration of mainland visitors. The top-left panel of Figure 6 shows the percentage change in medicine and cosmetic

\footnotetext{
${ }^{30}$ Legislative Council Secretariat, "Land-based Cross Boundary Passenger Trips", November 11, 2019. Retrieved from https://bit.ly/2PdsF4T

${ }^{31}$ Cosmetics and medicines are popular with parallel traders because they are easy to carry and have high demand in the mainland because of public concerns about food and drug safety. Appendix F provides details on how we construct the indicator.
} 
shops by district from 2007 to 2017 . We see that the growth was especially rapid in the area near the border checkpoints, confirming that it is one of the areas where the influx of mainland visitors was the greatest.

Having established the validity of this proxy, we now move to examine two sets of politically significant outcomes. The top-right and middle panels of Figure 6 illustrate the patterns for individual-level political and group attitudes, using data from multiple years of the Hong Kong Election Study (HKES http: //hkelectonstudy .org). We see that in areas closer to the checkpoints and the ERL, respondents tend to (a) express more agreement with the statement "there are too many mainland Chinese immigrants in Hong Kong", (b) to identify themselves more as Hong Kongers than as Chinese, and (c) to report greater dissatisfaction with the current state of democracy in the city. In Online Appendix, we subject these patterns to a more rigorous set of regression tests that control for a variety of individual and environmental covariates. The regression estimates again confirm that closeness to those cross-border transportation hubs is positively and significantly associated with the intensity of localist sentiment and pro-democracy attitudes (Table A.10).

In addition to public opinion, we also look at outcomes of legislative elections. The bottom row of Figure 6 displays the district-level change in the vote margin won by pro-regime political candidates in Hong Kong's two most recent Legislative Council elections (from 2008 to 2012, and from 2012 to 2016). We see a similar pattern: In the northern districts that intersect with the ERL, the electoral performance of pro-regime candidates deteriorated considerably relative to the rest of the city in both 2012 and 2016, a period that coincided with the massive influx of mainland visitors (for regression estimates, see Table A.11 and Figure A.11). Taken together, the observational evidence paints a picture consistent with the experimental results: The spatial distribution of mainland visitors corresponds closely with variations in both the intensity of negative outgroup attitudes and the strength of electoral support for opposition candidates. 
Figure 6: East Rail Line and Spatial Variations in Commercial Landscape, Public Attitudes, and Electoral Outcomes
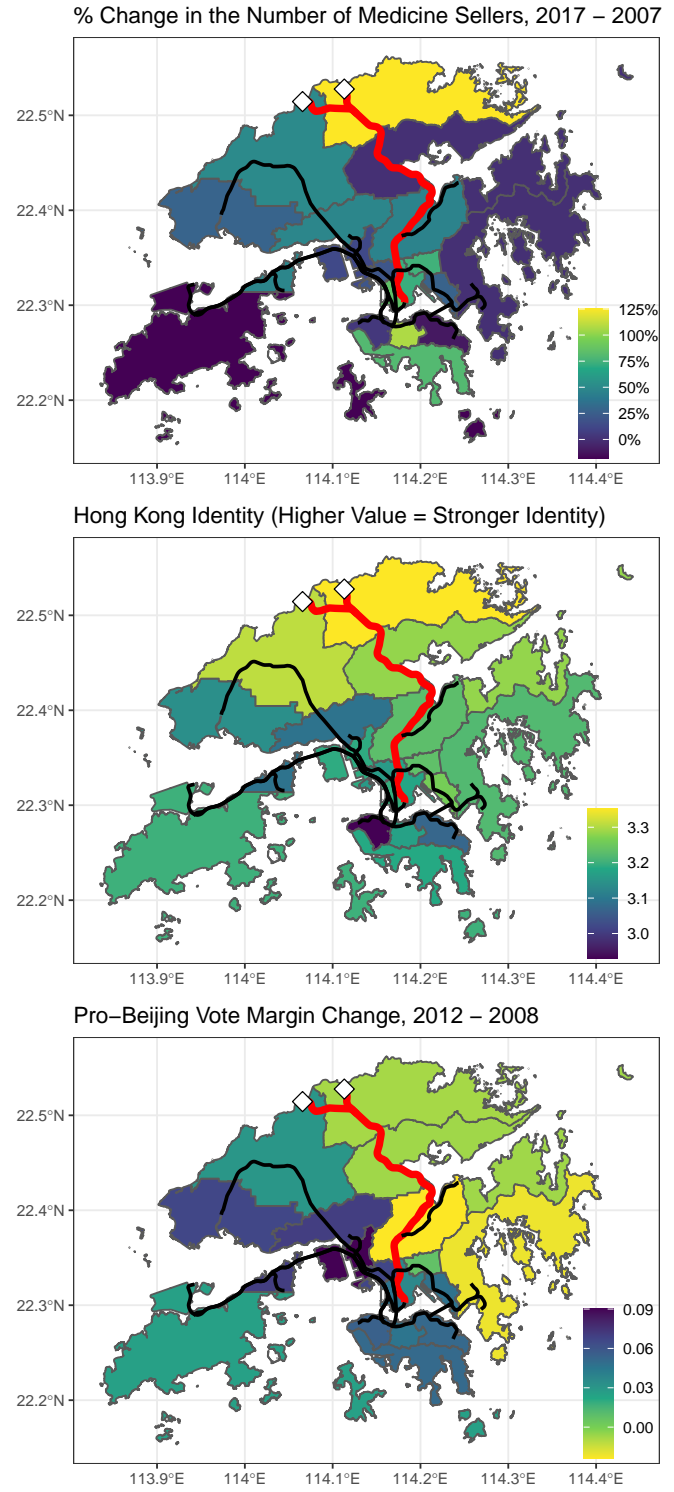
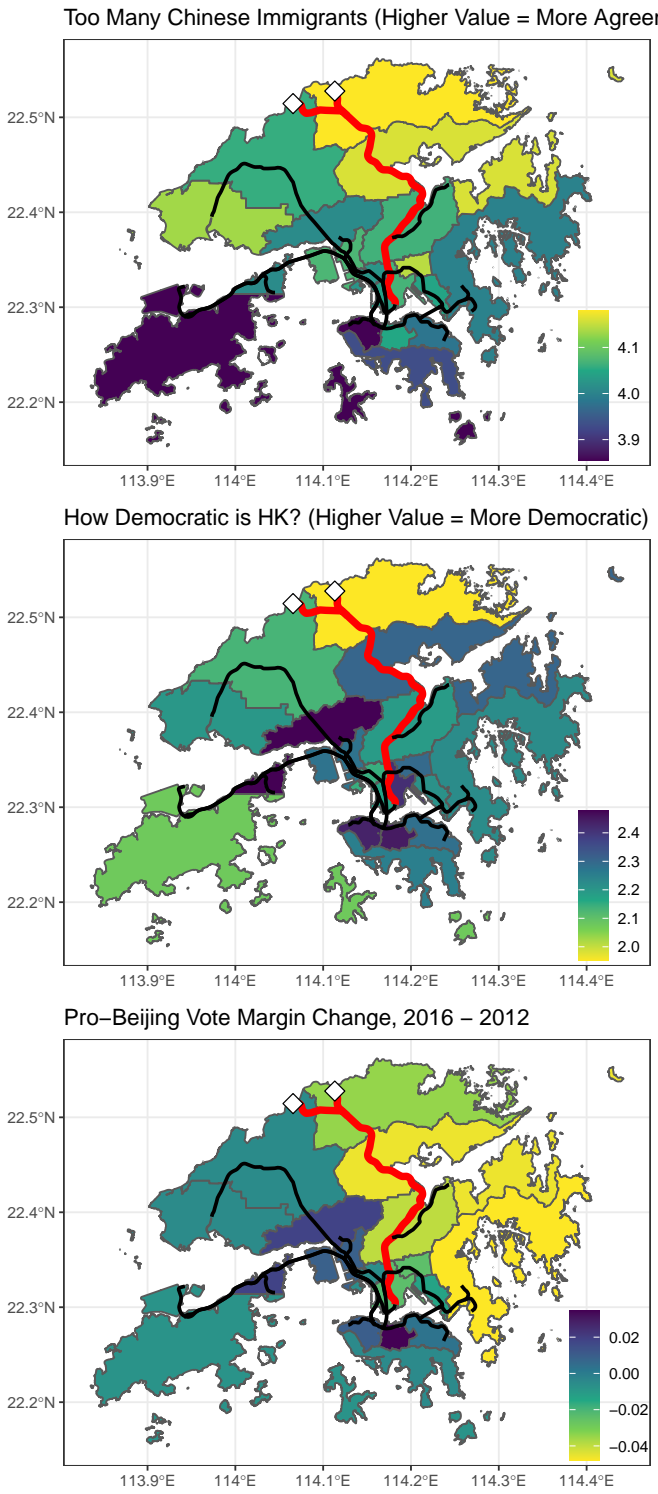

Note: This figure illustrates the over time district-level changes in commercial landscape, local public opinion, and the electoral performance of the pro-regime candidates. Public opinion data are drawn from Hong Kong Election Study (2015-2017). Each sub-figure presents aggregate responses from one survey question. The detailed question wording and coding rules can be found in Table A.8. Yellow (lighter) color indicates responses that reflect stronger localist/pro-democracy preferences, and blue (darker) color indicates the opposite. The red line denotes the ERL and the black lines denote the rest of the rail/subway network (as of December 2016). The two border checkpoints, Lo $\mathrm{Wu}(\mathrm{LW})$ and Lok Ma Chau (LMC), are marked by white diamond shapes. The figure shows that both the post-2008 influx of mainland Chinese and the subsequent rise of anti-China and pro-democracy sentiments tend to concentrate in districts near the ERL and the border checkpoints. For numerical results from regression analyses, see Tables A.10 and A.11 in Online Appendix. 


\section{Conclusion}

The question of what motivates ordinary citizens to join the fight for democracy is crucial for understanding both the nature of pro-democracy movements and their likely consequences. A central claim of this article is that even the relatively mundane form of inter-group grievances can sometimes generate powerful impetus for political change. Focusing on Hong Kong as a case, we conducted an array of experimental and observational studies to show how fear and resentment against the influx of large numbers of immigrants and visitors from mainland China contributed to the mobilization for democratic change by the disenfranchised local public. Our first experiment shows that those who harbor negative feelings about the mainland Chinese are more likely to raise their support for democracy when their outgroup attitudes are made salient. The second experiment further demonstrates that priming the vast scale of mainland Chinese influx is effective in altering both local subjects' outgroup attitudes and their support for democratization. Furthermore, we provide corroborating observational evidence from representative surveys and elections, showing that both group-based sentiments and support for democracy are stronger in areas more physically accessible to mainland visitors.

Results from this study underscore the importance of group-based political identities in driving regime transitions. Pioneering works on Eastern European transitions have argued that nationalist sentiments played a central role in mobilizing anti-regime protests that eventually led to the disintegration of the Soviet bloc (Beissinger 2002; Kubik 1994; Nodia 1992). While the existing studies typically take a macro-level perspective that treats countries or protest events as the unit of analysis, our study complements this perspective by addressing the critical micro-level question of how group-based sentiments are activated in the minds of movement participants. We also provide an additional mechanism as to how nationalist sentiment can arise. Instead of seeing it as solely a reaction to the domination by foreign elites (Anderson 1991; Beissinger 2002), our analyses suggest daily contact with ordinary members from politically salient outgroups can also help foster and reinforce group-based consciousness among members of the disenfranchised local ingroup. This finding helps to broaden our understanding of the range of possible tactics that national elites 
may use to evoke mobilization among mass followers.

The finding that deepened socioeconomic integration with mainland China has helped to create demand for democratization in Hong Kong enriches our knowledge about the transnational impacts of China's rise on the domestic politics of other countries and regions. Existing studies on the "China shock" in the United States and Europe have found that job loss caused by import competition with Chinese products has resulted in rightward shifts in ideological affiliation and voting patterns among non-Hispanic whites (Autor et al. 2020) and changes in public preferences toward protectionism and isolationism (Colantone and Stanig 2018). Interestingly, however, rather than creating support for anti-democratic, authoritarian platforms, as it has done in the West, negative reactions toward the competitive pressure from a rising China has translated into more vocal demand for democracy in Hong Kong. Similar to the Hong Kong case, recent pro-democracy protests in Thailand and Myanmar also featured elements that oppose China's increased economic involvement and physical presence in their countries. ${ }^{32}$ A fruitful direction for future research would be to explore how local politics reacts to the growing Chinese presence and why those reactions vary across different institutional and geopolitical contexts.

Finally, it is important to stress that by highlighting the inter-group aspect of Hong Kong's prodemocracy movements, our intention is not to trivialize the movement in any way, nor to suggest that inter-group appeals were the only thing that motivated mass participation. Many who took part in the movement were genuinely inspired by democracy's lofty appeals and have made great personal sacrifices for this cause. However, our findings do suggest that we need to have a more nuanced and contextualized view about how pro-democracy mobilization occurred on the ground and devote more effort to unpack the concrete experiences and incentives that drove individuals' actions. A clear understanding of the various causes behind mass mobilization is crucial for an accurate assessment of the welfare consequences of large-scale social movements.

\footnotetext{
${ }^{32}$ See, for example, "Why are Myanmar's anti-coup protesters angry at China?", South China Morning Post, 16 Mar 2021. https://bit.ly/3a3pVlk, and "How Milk Tea Became an Anti-China Symbol", The Atlantic, 13 Oct 2020. https://bit.ly/3wNi70U.
} 


\section{References}

Abizadeh, Arash. 2012. “On the Demos and Its Kin: Nationalism, Democracy, and the Boundary Problem.” American Political Science Review 106 (4): 867-882.

Acemoglu, Daron, and James A. Robinson. 2005. Economic Origins of Dictatorship and Democracy. Cambridge: Cambridge University Press.

Anderson, Benedict. 1991. Imagined Communities : Reflections on the Origin and Spread of Nationalism. London New York: Verso.

Ansell, Ben W, and David J Samuels. 2014. Inequality and Democratization: An Elite-Competition Approach. Cambridge University Press.

Autor, David, et al. 2020. "Importing Political Polarization? The Electoral Consequences of Rising Trade Exposure.” American Economic Review 110 (10): 3139-83.

Barth, Fredrik. 1969. Ethnic Groups and Boundaries: the Social Organization of Culture Difference. Edited by Fredrik Barth. Olso: Universitetsforlaget.

Bedford, Olwen, and Kwang-Kuo Hwang. 2006. Taiwanese Identity and Democracy. Palgrave Macmillan US.

Beissinger, Mark R. 2002. Nationalist Mobilization and the Collapse of the Soviet State. Cambridge University Press.

Bloom, Pazit Ben-nun, Gizem Arikan, and Marie Courtemanche. 2015. "Religious Social Identity, Religious Belief, and Anti-Immigration Sentiment.” American Political Science Review 109 (2): 203-221.

Bogardus, Emory S. 1925. “Measuring Social Distance.” Journal of Applied Sociology 9:299-308.

— . 1926. "Social Distance in the City." Proceedings and Publications of the American Sociological Society 20:40-46.

Boix, Carles. 2003. Democracy and Redistribution. Cambridge: Cambridge University Press. 
Chin, Wan. 2011. “Hong Kong City-State Discourse 香港城邦論.” Hong Kong: Enrish Publishing 天窗出版.

Cohen, Philip N. 1996. "Nationalism and Suffrage: Gender Struggle in Nation-Building America.” Signs 21 (3): 707-727.

Colantone, Italo, and Piero Stanig. 2018. "Global Competition and Brexit." American Political Science Review 112, no. 2 (): 201-218.

Collier, Ruth Berins. 2009. Paths Toward Democracy: The Working Class and Elites in Western Europe and South America. Cambridge University Press.

Dakin, Mary I. 1992. Nationalism and Democratization: The Case of Ethnic Russians in Newly Independent Latvia. The National Council for Soviet and East European Research.

Diamond, Larry Jay. 1999. Developing Democracy: Toward Consolidation. Baltimore: Johns Hopkins University Press.

Emerson, Rupert. 1960. From Empire to Nation : The Rise to Self-assertion of Asian and African Peoples. Cambridge: Harvard University Press.

Enos, Ryan D. 2015. "What the Demolition of Public Housing Teaches Us about the Impact of Racial Threat on Political Behavior.” American Journal of Political Science 60 (1): 123-142.

Forbes, H. D. 1997. Ethnic Conflict : Commerce, Culture, and the Contact Hypothesis. New Haven: Yale University Press.

Giles, Michael W., and Melanie A. Buckner. 1993. "David Duke and Black Threat: An Old Hypothesis Revisited.” The Journal of Politics 55, no. 3 (): 702-713.

Golway, Terry. 2014. Machine Made : Tammany Hall and the Creation of Modern American Politics. New York: Liveright Publishing Corporation, a division of W.W. Norton \& Company.

Hobsbawm, Eric J. 1990. Nations and Nationalism since 1780: Programme, Myth, Reality. Cambridge University Press. 
Huang, Haifeng. 2015. "International Knowledge and Domestic Evaluations in a Changing Society: The Case of China." American Political Science Review 109 (3): 613-634.

Huntington, Samuel P. 1991. The Third Wave: Democratization in the Late Twentieth Century. Norman: University of Oklahoma Press.

Imai, Kosuke, et al. 2011. "Unpacking the Black Box of Causality: Learning about Causal Mechanisms from Experimental and Observational Studies." American Political Science Review 105 (4): 765-789.

Inglehart, Ronald, and Christian Welzel. 2005. Modernization, Cultural Change, and Democracy: The Human Development Sequence. Cambridge: Cambridge University Press.

Kalyvas, Stathis N. 2003. "The Ontology of "Political Violence": Action and Identity in Civil Wars." Perspectives on Politics 1 (03): 475-494.

Key, V. O. 1949. Southern Politics in State and Nation. Knoxville: TN: University of Tennessee Press.

Kubik, Jan. 1994. The Power of Symbols against the Symbols of Power : The Rise of Solidarity and the Fall of State Socialism in Poland. University Park, PA: Pennsylvania State University Press.

Kuran, Timur. 1991. "Now out of Never: The Element of Surprise in the East European Revolution of 1989." World Politics 44 (1): 7-48.

Lee, Francis L. F., et al. 2019. "Hong Kong's Summer of Uprising: From Anti-Extradition to AntiAuthoritarian Protests." China Review 19 (4): 1-32.

LeVine, Robert A., and Donald T. Campbell. 1972. Ethnocentrism: Theories of Conflict, Ethnic Attitude, and Group Behavior. New York: John Wiley.

Li, Ling-Hin, Ka Shing Cheung, and Sue Yurim Han. 2018. "The impacts of cross-border tourists on local retail property market: an empirical analysis of Hong Kong." Journal of Property Research 35 (3): 252-270. 
Linz, Juan J., and Alfred Stepan. 1996. Problems of Democratic Transition and Consolidation. Johns Hopkins University Press.

Lohmann, Susanne. 1994. “The Dynamics of Informational Cascades: The Monday Demonstrations in Leipzig, East Germany, 1989-91.” World Politics 47 (1): 42-101.

Lowe, John, and Stephan Ortmann. 2020. “Unmasking Nativism in Asia's World City: Graffiti and Identity Boundary Un/making in Hong Kong." Continuиm 34 (3): 398-416.

Ma, Ngok. 2015. "The Rise of "Anti-China" Sentiments in Hong Kong and the 2012 Legislative Council Elections." The China Review: 39-66.

Mann, Michael. 2004. The Dark Side of Democracy. Cambridge: Cambridge University Press.

McNamee, Lachlan, and Anna Zhang. 2019. "Demographic engineering and international conflict: Evidence from China and the Former USSR." International Organization 73 (2): 291-327.

Meltzer, Allan, and Scott F. Richard. 1981. "A Rational Theory of the Size of Government.” Journal of Political Economy 89 (5): 914-927.

Moore, Barrington Jr. 1966. Social Origins of Dictatorship and Democracy. Boston: Beacon Press.

Nielsen, Francois. 1980. "The Flemish Movement in Belgium After World War II: A Dynamic Analysis." American Sociological Review 45 (1): 76.

Nodia, Ghia. 1992. "Nationalism and Democracy." Journal of Democracy 3 (4): 3-22.

Olzak, Susan, Suzanne Shanahan, and Elizabeth H. McEneaney. 1996. "Poverty, Segregation, and Race Riots: 1960 to 1993.” American Sociological Review 61 (4): 590.

Olzak, Susan, Suzanne Shanahan, and Elizabeth West. 1994. "School Desegregation, Interracial Exposure, and Antibusing Activity in Contemporary Urban America." American Journal of Sociology 100 (1): 196-241.

Przeworski, Adam. 1999. "Minimalist Conception of Democracy: A Defense." In Democracy's Value, ed. by Ian Shapiro and Casiano Hacker-Cordon. Cambridge: Cambridge University Press. 
Sambanis, Nicholas, and Moses Shayo. 2013. "Social Identification and Ethnic Conflict.” American Political Science Review 107 (2): 294-325.

Shayo, Moses. 2009. “A Model of Social Identity with an Application to Political Economy: Nation, Class, and Redistribution.” American Political Science Review 103 (2): 147-174.

Sherif, Muzafer. 1966. In Common Predicament: Social Psychology of Intergroup Conflict and Cooperation. Boston: Houghton Mifflin Company.

Sidanius, Jim, and Felicia Pratto. 1999. Social Dominance: An Intergroup Theory of Social Hierarchy and Oppression. Cambridge University Press.

Sung, Yun-Wing, et al. 2015. "The economic benefits of mainland tourists for Hong Kong: The individual visit scheme (IVS) and multiple entry individual visit endorsements (M-Permit)." Shanghai-Hong Kong Development Institute, Occasional Paper, no. 34.

Tajfel, Henri, et al. 1971. "Social Categorization and Intergroup Behaviour." European Journal of Social Psychology 1 (2): 149-178.

Taylor, Charles. 1998. “The Dynamics of Democratic Exclusion.” Journal of Democracy 9 (4): $143-156$.

Tilly, Charles. 1978. From Mobilization to Revolution. Reading, Mass: Addison-Wesley Pub. Co.

Tocqueville, Alexis de. 1856. The Old Regime and the French Revolution. New York: Anchor Books.

Transue, John E. 2007. “Identity Salience, Identity Acceptance, and Racial Policy Attitudes: American National Identity as a Uniting Force.” American Journal of Political Science 51 (1): 7891.

Turner, John. 1984. "Social Identification and Psychological Group Formation.” In The Social Dimension: European Developments in Social Psychology, ed. by Henri Tajfel, 518-538. New York: Cambridge University Press. 
Veg, Sebastian. 2015. “Legalistic and Utopian: Hong Kong's Umbrella Movement.” New Left Review 92 (March-April): 55-73.

Vetik, Raivo. 1993. "Ethnic Conflict and Accommodation in Post-Communist Estonia." Journal of Peace Research 30 (3): 271-280.

Wong, Stan Hok-Wui. 2017. "Gerrymandering in Electoral Autocracies: Evidence from Hong Kong.” British Journal of Political Science 49 (2): 579-610.

Wong, Stan Hok-Wui, Ngok Ma, and Wai-man Lam. 2018. "Immigrants As Voters in Electoral Autocracies: The Case of Mainland Chinese Immigrants in Hong Kong." Journal of East Asian Studies 18 (1): 67-95.

Wong, Stan Hok-Wui, and Kin Man Wan. 2018. "The housing boom and the rise of localism in Hong Kong: Evidence from the legislative council election in 2016." China Perspectives 2018 (2018/3): 31-40.

Yang, David D. 2007. “Classing Ethnicity. Class, Ethnicity, and the Mass Politics of Taiwan's Democratic Transition.” World Politics 59 (4): 503-538.

Zhao, Dingxin. 2004. The Power of Tiananmen: State-Society Relations and the 1989 Beijing Student Movement. University of Chicago Press. 


\section{Online Appendix (Not for Publication) for Inter-Group Relations and Support for Democratization: Evidence from Hong Kong}

\section{Table of Contents}

A Ethical Considerations

B Summary Statistics for Two Survey Experiments A-3

$\begin{array}{lll}\text { C Numerical Results and Robustness Checks for Study } 1 & \text { A-9 }\end{array}$

D Original Texts of the Treatment and Outcome Questions for Study $1 \quad$ A-13

D.1 Treatment . . . . . . . . . . . . . . . . . . . . . A-13

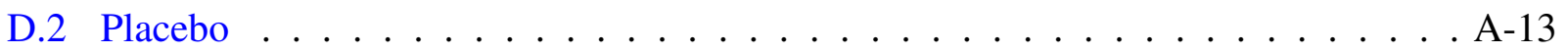

D.3 Democratic Attitudes . . . . . . . . . . . . . . . A-13

$\begin{array}{lll}\text { E } & \text { Additional Information \& Robustness Checks for Study } 2 & \text { A-15 }\end{array}$

E.1 Original Treatment Texts and English Translation . . . . . . . . . . . . . . A-15

$\begin{array}{lll}\text { F Additional Information for the Observational Studies } & \text { A-17 }\end{array}$

F.1 Data on the Number of Medicine Shops Over Time . . . . . . . . . . . . . A A-17

F.2 Calculating Closeness to Checkpoints (via Public Transit) . . . . . . . . . . . A-17

F.3 Data on Public Opinion and Election Results . . . . . . . . . . . . . . . A-18

F.4 Results . . . . . . . . . . . . . . . . . . . . A-21 


\section{A Ethical Considerations}

Our research was approved by our institution's institutional review board. In this section, we discuss how we have approached the main ethical issues as outlined by APSA's Principles and Guidance for Human Subjects Research.

For both survey experiments, participation was completely voluntary. Participants were recruited via university mass mail, with no consequence if they choose not to participate. At the very beginning of the survey, participants were informed about the length, pay, and the nature (i.e. a study of Hong Kong students' social attitudes) of the study. They were also informed of the identity of the PIs and of the channels to seek redress (by either contacting the PIs or by lodging a complaint to the institutional review board). Participants had to give explicit consent (by checking the response "I agree to continue" in a multiple choice question) in order to proceed with taking the survey. They could discontinue the survey at any time. There was no deception involved in the survey.

Participants were paid a minimum of HK\$ 30 (US\$ 3.9) for Study 1 and HK\$ 55 (US\$ 7.0) for Study 2. Both studies took, on average, 20-30 minutes to finish. The hourly rate we offer is on par with the going rate for 30 minutes of work by a student research assistant, and significantly higher than the hourly minimum wage in Hong Kong in 2020 (HK\$ 37.5, or US\$ 4.8 per hour).

In terms of potential harm, there are several issues that we considered. First, since we had to collect subjects' personal information in order to verify their eligibility and process payments, data confidentiality is a natural concern. Some of our survey questions, such as those that asked about participants' protest experiences and donations to pro-democracy organizations, also elicit information that may be considered politically or legally sensitive in certain context. To protect the identity of our participants, we stored all the experiment data offline in on-campus, passwordprotected computers while the study was still on-going, and permanently deleted all the identifying information of our participants as soon the payments/lotteries have been processed. During the survey, we also avoided directly questioning our participants about their participation in policeprotester clashes or any illegal activities. Instead, we asked if our participants had witnessed any clashes, and elicited their responses to sensitive questions using the item count technique.

Another concern is that our project might influence participants' preferences toward certain groups (i.e., mainland Chinese) or their propensity to participate in protests. Given that our treatments are relatively mild and brief, we do not expect that they would significantly affect our respondents' attitudes in any permanent ways. As a precautionary measure, we debriefed our participants at the end of the experiment, emphasizing that the information presented to them during the study was tailored specifically to the study, and that our subjects should not change their opinions about any groups or issues simply based on such information alone. Moreover, at the time when our surveys were fielded (after March, 2020), large-scale offline protests had largely ceded (and much of the resistance were moved online) because of the coronavirus outbreak in the city. It is thus unlikely that our brief treatments would make our subjects more likely to engage in risky offline protests. 


\section{B Summary Statistics for Two Survey Experiments}

Figure A.1: Comparing the Survey Sample with University Student Population
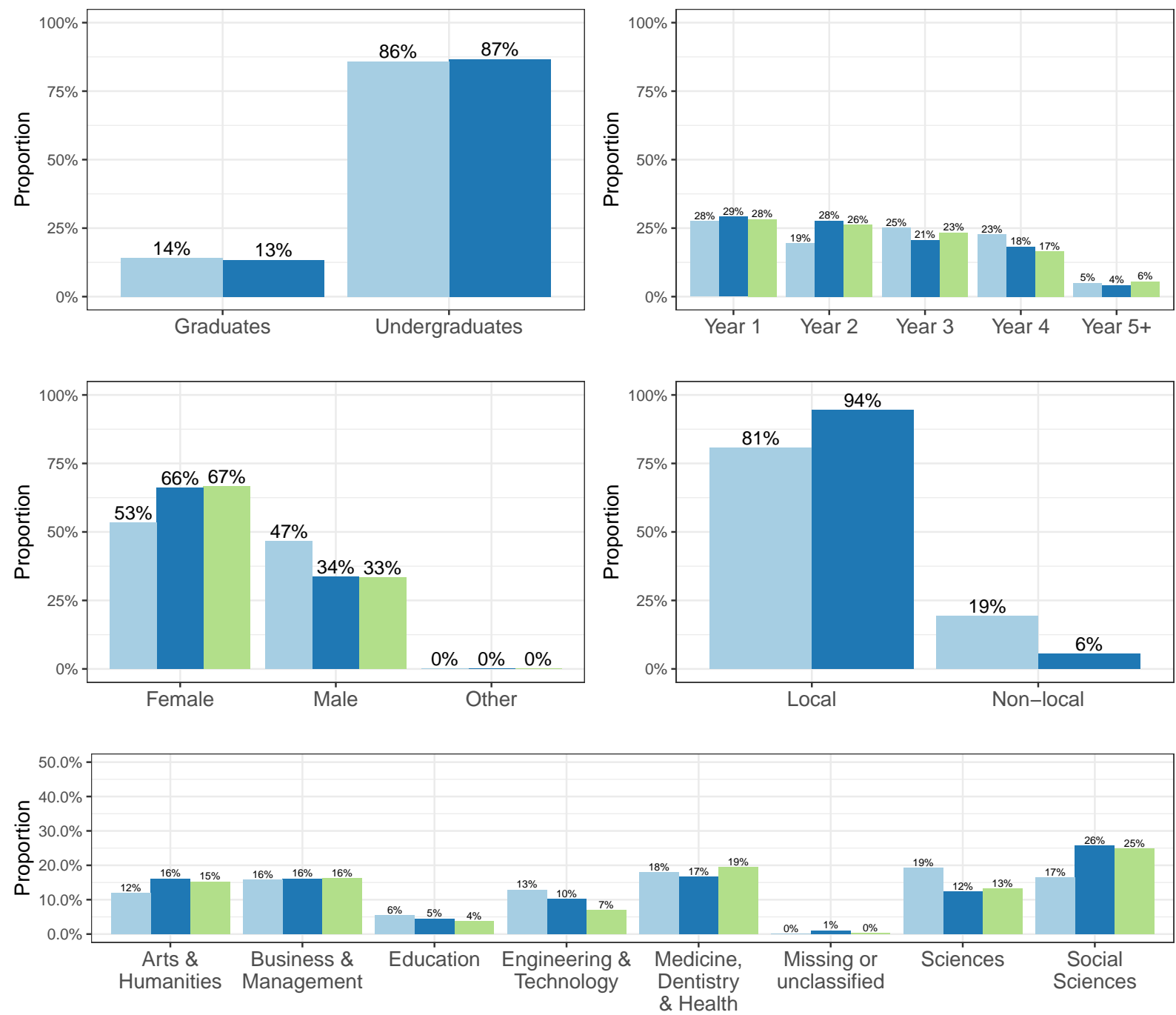

Population

Note: This figure compares the key demographic characteristics of our sample with the characteristics of the student population at the university where the survey was conducted. We therefore do not report the breakdown for level of study (undergraduate vs. graduate) and local origin for the second study because we only recruited local undergraduate students for that study (due to specific restrictions on the funding source). The population statistics were obtained from the University Grants Committee of Hong Kong (https://bit.ly/2WT1ron). 
Figure A.2: Distribution of Responses to Mainland Distance Questions (Study 1)

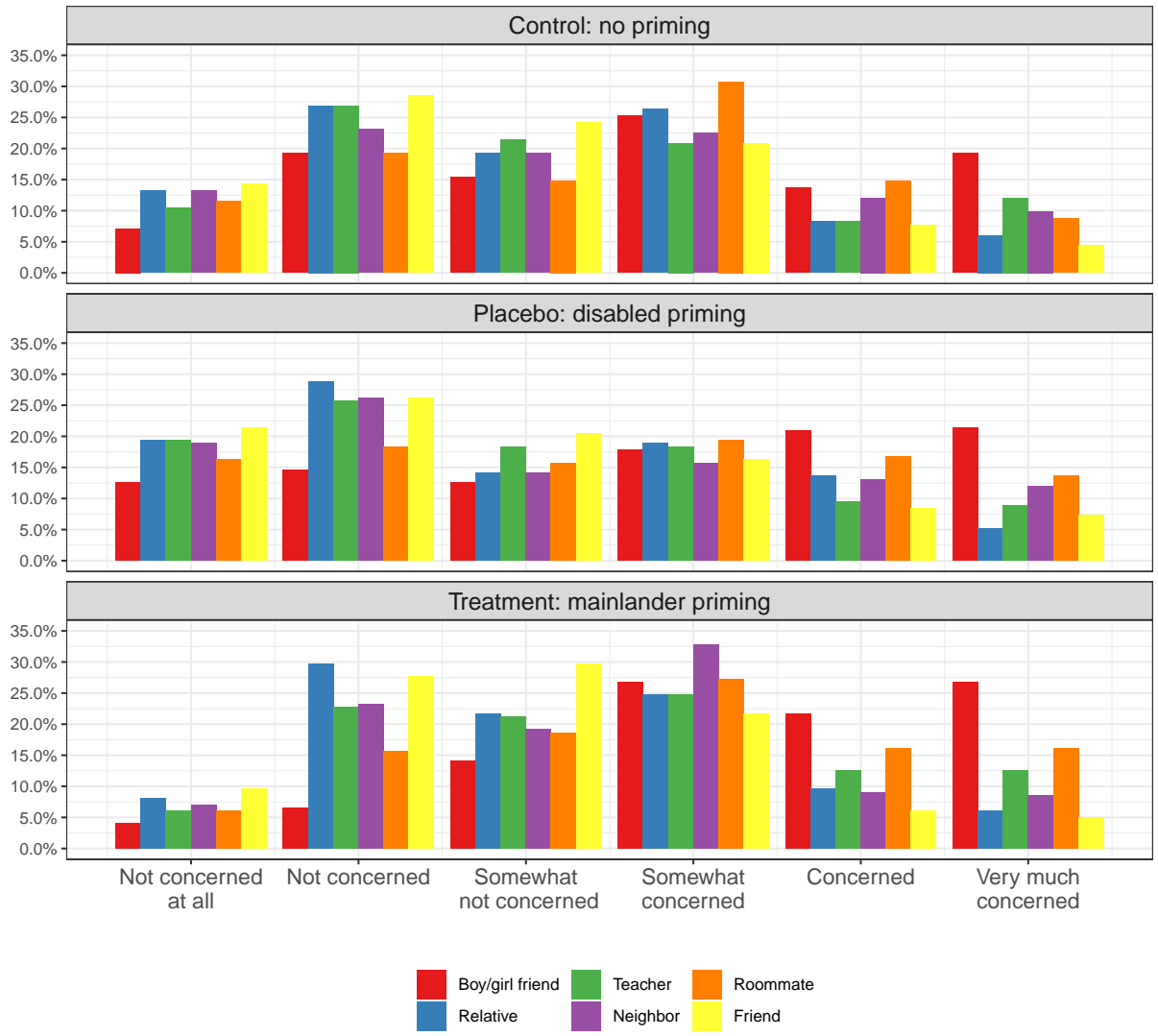

Figure A.3: Distribution of Responses to Mainland Distance Questions (Study 2)

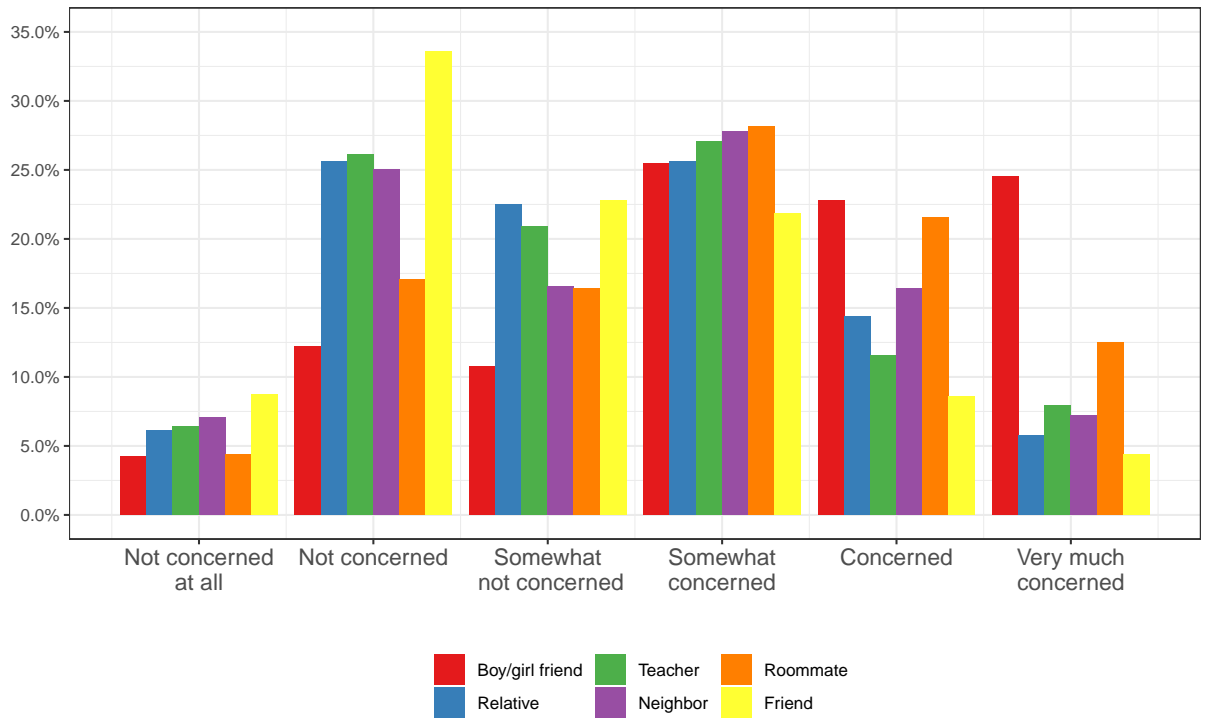


Figure A.4: Distribution of Key Outcome Variables (Study 1)
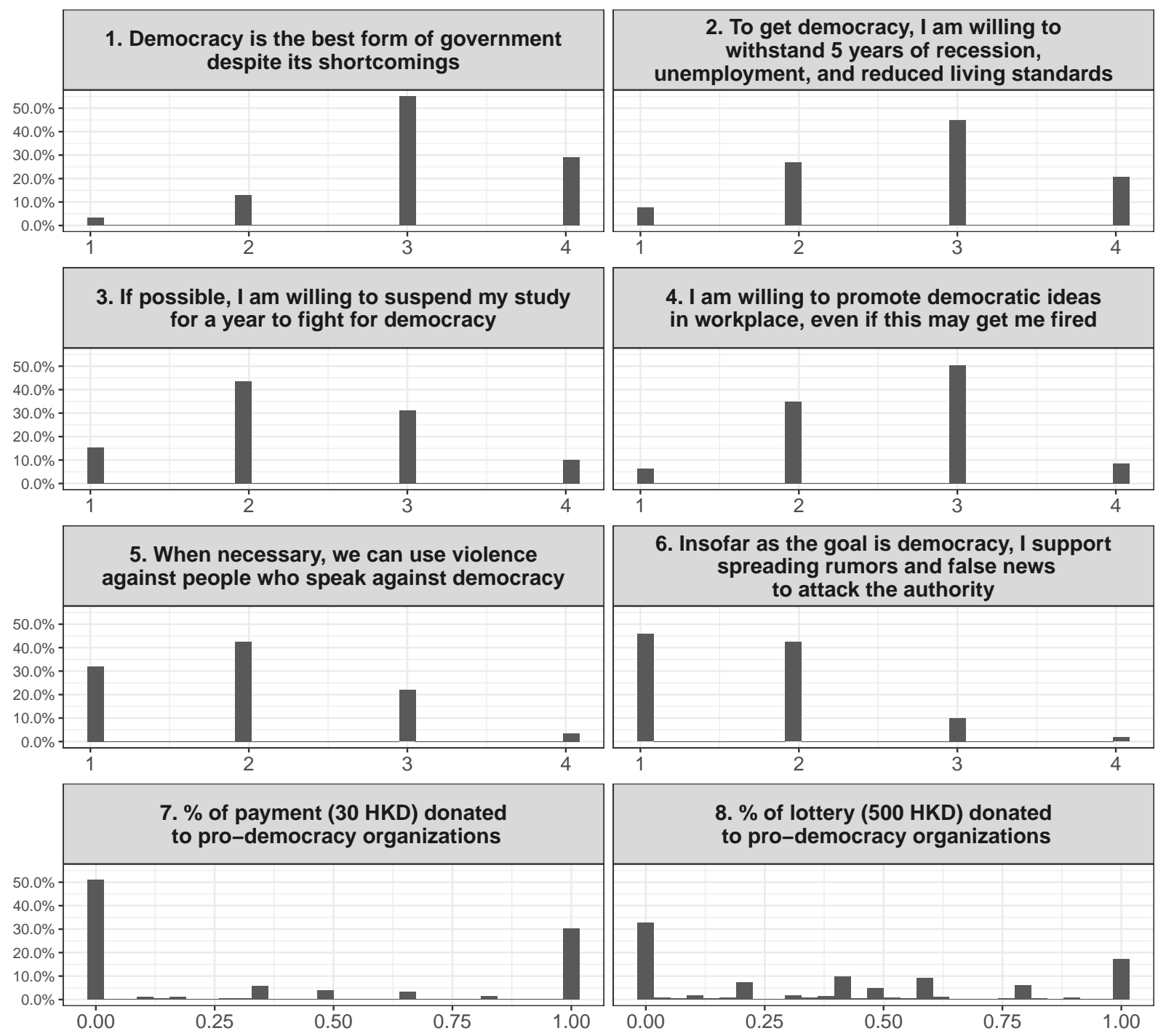

Note: This figure presents the distribution of key outcome variables for Study 1. For the first six panels, numerals 1 through 4 represent "strongly disagree", "somewhat disagree", "somewhat agree", and "strongly agree", respectively. 
Figure A.5: Distribution of Key Outcome Variables (Study 2)
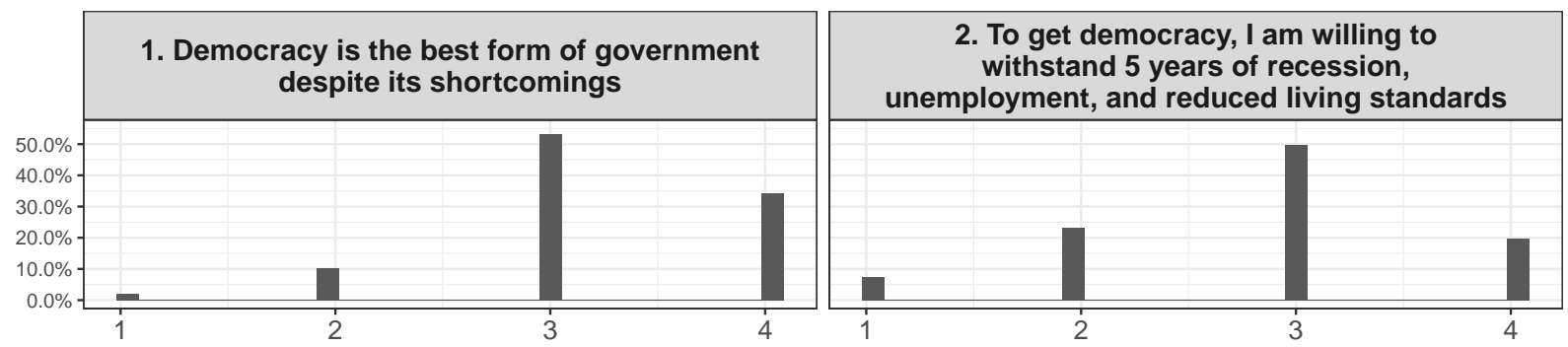

3. If possible, I am willing to suspend my study for a year to fight for democracy

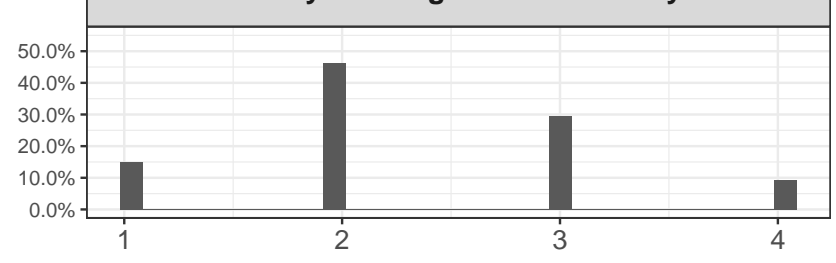

4. I am willing to promote democratic ideas in workplace, even if this may get me fired
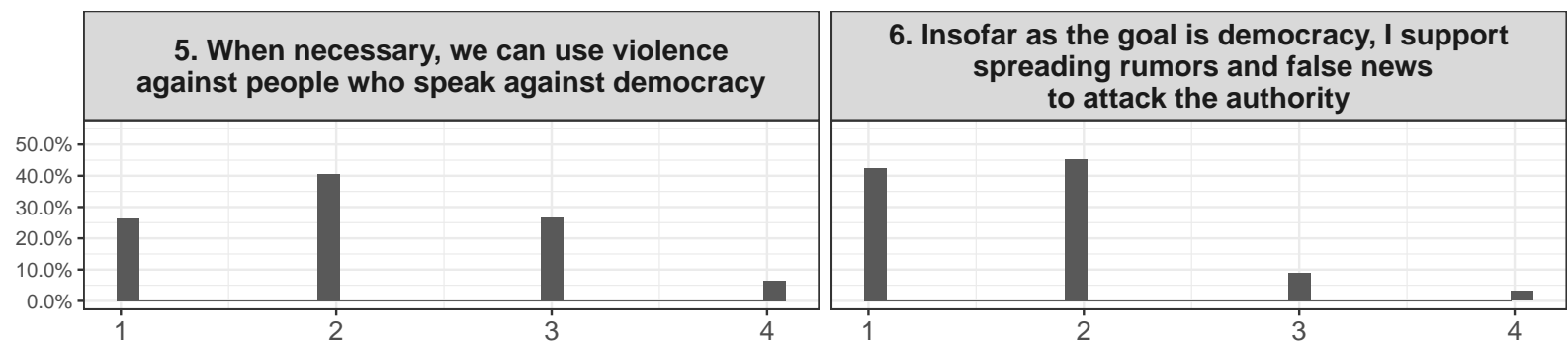

Note: This figure presents the distribution of key outcome variables for Study 2. For the first six panels, numerals 1 through 4 represent "strongly disagree", "somewhat disagree", "somewhat agree", and "strongly agree", respectively.

Figure A.6: Screeplots from Principal Component Analyses: Support for Democracy
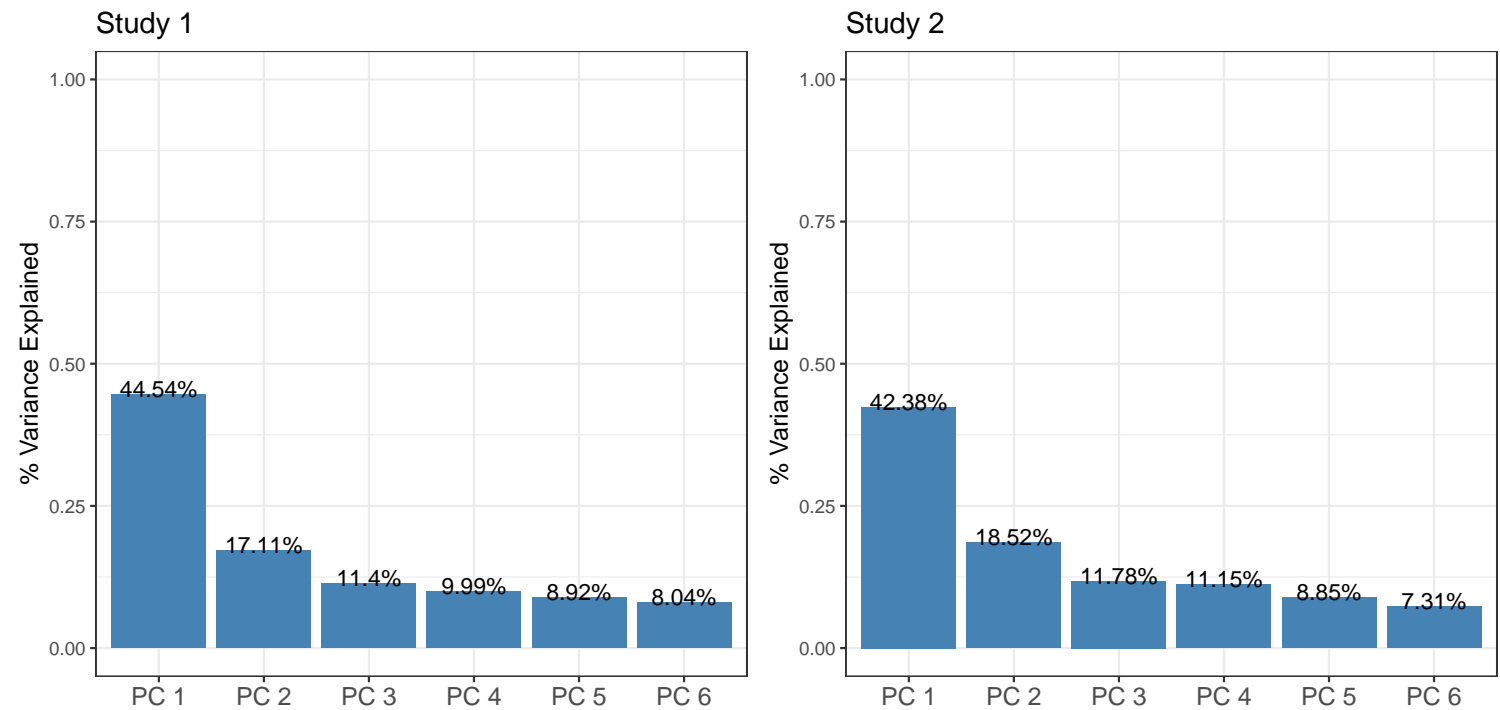
Figure A.7: Screeplots from Principal Component Analyses: Subjective Distance to Mainland Chinese
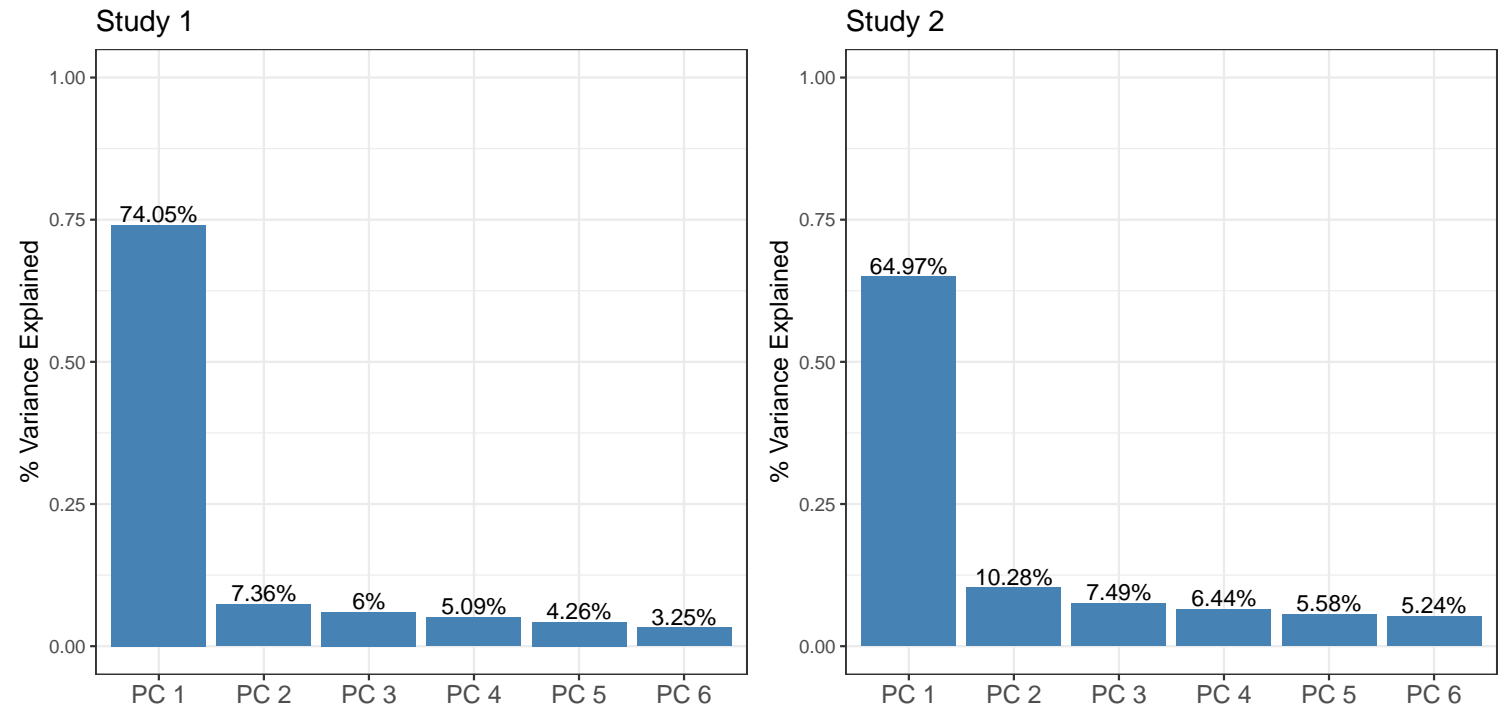

Figure A.8: Balance Checks: Study 1
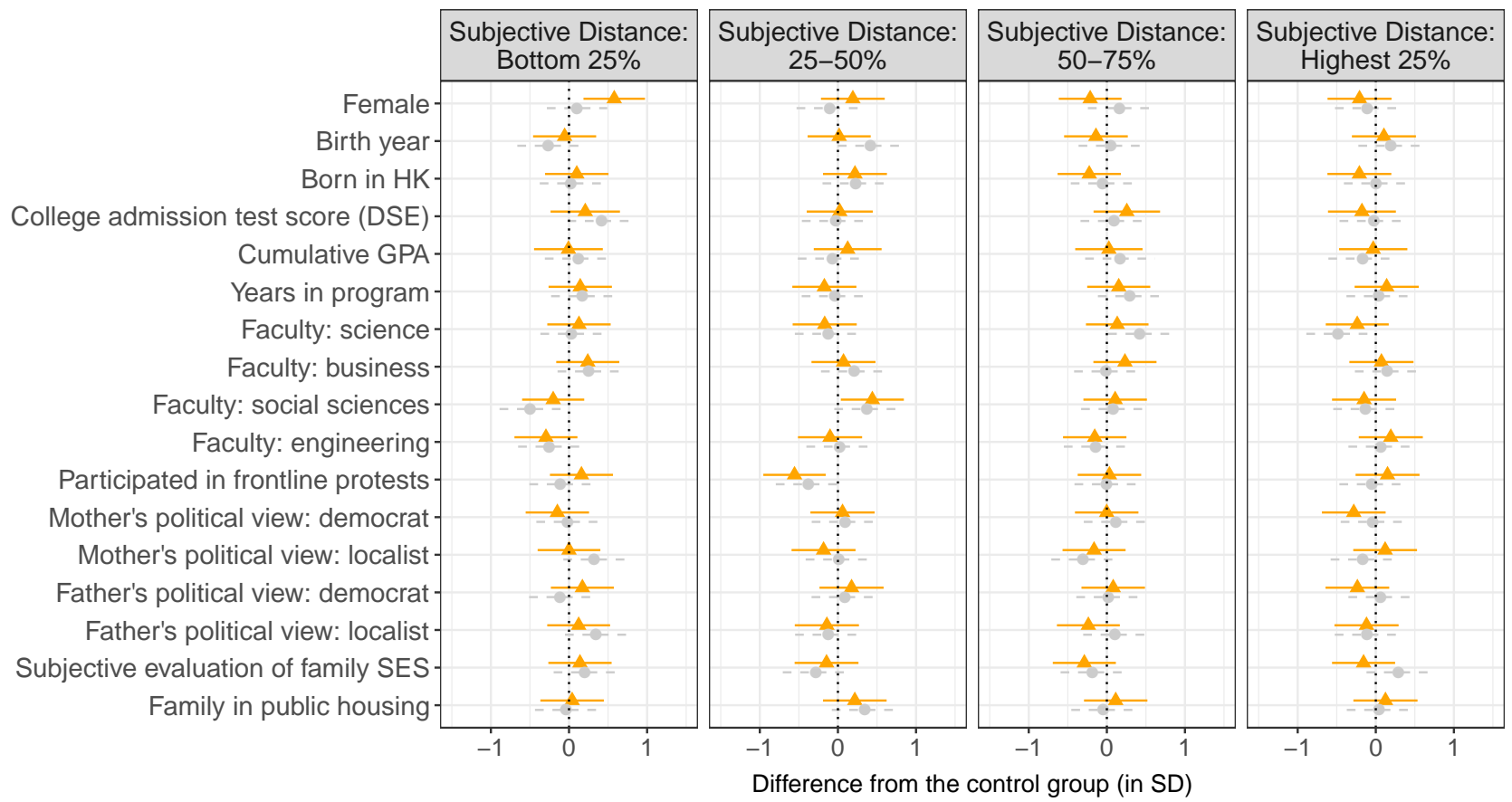

Difference from the control group (in SD)

Placebo group $\&$ Treatment group 


\section{Figure A.9: Balance Checks: Study 2}

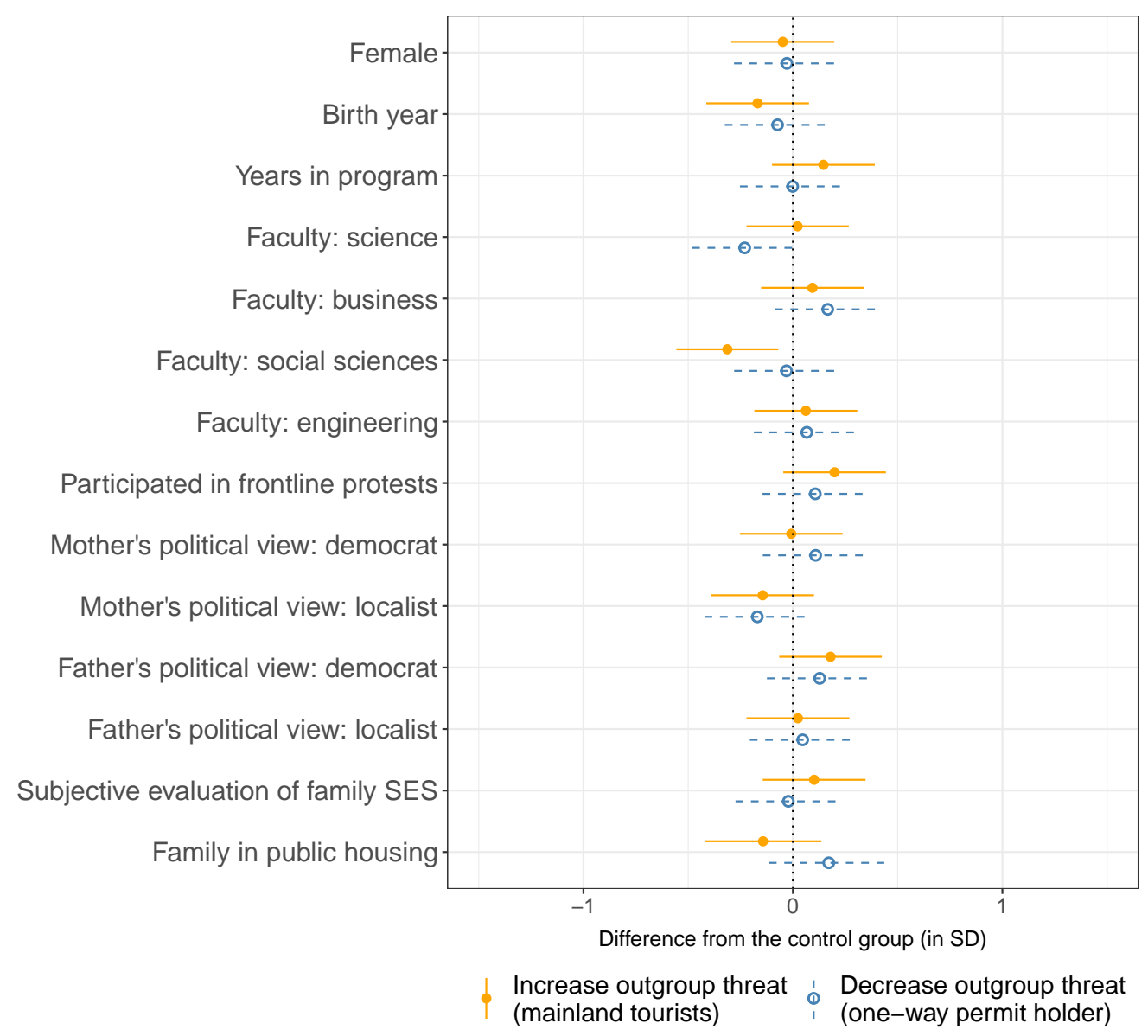




\section{Numerical Results and Robustness Checks for Study 1}

Table A.1: Numerical Results for the Top 25\% in Subjective Mainland Distance

\begin{tabular}{lcc}
\hline & \multicolumn{2}{c}{ Top 25\% in Mainland Distance } \\
\cline { 2 - 3 } & $\begin{array}{l}(1) \\
\text { Treatment vs. } \\
\text { Control }\end{array}$ & $\begin{array}{c}\text { Treatment vs. } \\
\text { Placebo }\end{array}$ \\
\hline Overall Support for Democracy (PCA) & $0.806^{* *}$ & $0.980^{* *}$ \\
& $(0.300)$ & $(0.297)$ \\
1. Democracy is the best form of government & 0.0580 & 0.198 \\
& $(0.149)$ & $(0.138)$ \\
2. Withstand five years of recession for democracy & $0.313^{*}$ & $0.416^{* *}$ \\
3. Suspend study for a year to fight for democracy & $(0.157)$ & $(0.158)$ \\
& $0.522^{* *}$ & $0.473^{* *}$ \\
4. Promote democratic ideas in workplace & $(0.187)$ & $(0.179)$ \\
5. Use violence against people who speak against democracy & $0.294^{*}$ & $0.428^{* *}$ \\
6. Support spreading rumors and false news to attack the authority & $(0.144)$ & $(0.144)$ \\
& 0.0875 & 0.116 \\
7. \% Donated to pro-democracy organizations (30 HKD payment) & $(0.189)$ & $(0.173)$ \\
& 0.248 & 0.215 \\
8. \% Donated to pro-democracy organizations (500 HKD Lottery) & $(0.164)$ & $(0.166)$ \\
& $0.149^{+}$ & $0.198^{*}$ \\
& $(0.0811)$ & $(0.0922)$ \\
\end{tabular}

Note: This table presents the baseline numerical results for those whose subjective mainland distance is in the top $25 \%$ quartile of their own group. Column 1 reports the difference in reported democratic attitudes between the treatment and the control group, and Column 2 reports the difference between the treatment and the placebo group. Robust standard errors are in parentheses.

${ }^{+} p<0.1,{ }^{*} p<0.05,{ }^{* *} p<0.01$ (two-tailed test) 
Table A.2: Robustness: Using Within-Group Tertile

\begin{tabular}{|c|c|c|c|}
\hline & $\begin{array}{l}\text { Overall Support for } \\
\text { Democracy (PCA) }\end{array}$ & $\begin{array}{c}\% \text { Donated to } \\
\text { Pro-Democracy } \\
\text { Organizations (from } \\
30 \text { HKD payment) }\end{array}$ & $\begin{array}{c}\% \text { Donated to } \\
\text { Pro-Democracy } \\
\text { Organizations (from } \\
500 \text { HKD Lottery) }\end{array}$ \\
\hline Treatment effect by mainland distance tertile & (1) & (2) & (3) \\
\hline Top $1 / 3$ & $\begin{array}{l}0.677^{* *} \\
(0.220)\end{array}$ & $\begin{array}{l}0.121^{+} \\
(0.070)\end{array}$ & $\begin{array}{c}0.058 \\
(0.060)\end{array}$ \\
\hline $33 \%$ to $66 \%$ & $\begin{array}{c}0.278 \\
(0.224)\end{array}$ & $\begin{array}{l}-0.075 \\
(0.067)\end{array}$ & $\begin{array}{l}-0.023 \\
(0.058)\end{array}$ \\
\hline Bottom 1/3 & $\begin{array}{l}-0.180 \\
(0.247)\end{array}$ & $\begin{array}{l}-0.090 \\
(0.066)\end{array}$ & $\begin{array}{l}-0.077 \\
(0.054)\end{array}$ \\
\hline Observations & 571 & 571 & 571 \\
\hline
\end{tabular}

Note: This table presents the heterogeneous treatment effects using the within-group tertile of distance to mainlanders as the moderating variable. Robust standard errors are in parentheses.

${ }^{+} p<0.1,{ }^{*} p<0.05,{ }^{* *} p<0.01$ (two-tailed test)

Table A.3: Robustness: Using Original Mainland Distance Quartile as the Moderating Variable

\begin{tabular}{|c|c|c|c|}
\hline & $\begin{array}{l}\text { Overall Support } \\
\quad \text { (PCA) }\end{array}$ & $\begin{array}{c}\% \text { Donated from } 30 \\
\text { HKD payment }\end{array}$ & $\begin{array}{c}\% \text { Donated from } 500 \\
\text { HKD Lottery }\end{array}$ \\
\hline Treatment effect by dist. to mainlanders & (1) & (2) & (3) \\
\hline Top $25 \%$ & $\begin{array}{c}0.861^{* * *} \\
(0.242)\end{array}$ & $\begin{array}{c}0.194^{*} \\
(0.079)\end{array}$ & $\begin{array}{c}0.101 \\
(0.068)\end{array}$ \\
\hline $50 \%$ to $70 \%$ & $\begin{array}{l}-0.062 \\
(0.231)\end{array}$ & $\begin{array}{l}-0.138 \\
(0.075)\end{array}$ & $\begin{array}{l}-0.041 \\
(0.066)\end{array}$ \\
\hline $25 \%$ to $50 \%$ & $\begin{array}{l}-0.031 \\
(0.255)\end{array}$ & $\begin{array}{l}-0.022 \\
(0.072)\end{array}$ & $\begin{array}{l}-0.054 \\
(0.058)\end{array}$ \\
\hline Bottom $25 \%$ & $\begin{array}{l}-0.350 \\
(0.323)\end{array}$ & $\begin{array}{l}-0.126 \\
(0.089)\end{array}$ & $\begin{array}{l}-0.119 \\
(0.074)\end{array}$ \\
\hline Observations & 571 & 571 & 571 \\
\hline
\end{tabular}

Note: This table presents the heterogeneous treatment effects. The distance quartile is based on the entire sample instead of on each treatment group. Robust standard errors are in parentheses.

${ }^{+} p<0.1,{ }^{*} p<0.05,{ }^{* *} p<0.01$ (two-tailed test) 
Table A.4: Robustness: Using a Continuous Measure for Mainland Distance

\begin{tabular}{|c|c|c|c|}
\hline & $\begin{array}{l}\text { Overall Support for } \\
\text { Democracy (PCA) }\end{array}$ & $\begin{array}{c}\% \text { Donated to } \\
\text { Pro-Democracy } \\
\text { Organizations (from } \\
30 \text { HKD payment) }\end{array}$ & $\begin{array}{c}\% \text { Donated to } \\
\text { Pro-Democracy } \\
\text { Organizations (from } \\
500 \text { HKD Lottery) }\end{array}$ \\
\hline & (1) & (2) & (3) \\
\hline Mainland distance $\times$ treatment & $\begin{array}{l}0.273^{* *} \\
(0.084)\end{array}$ & $\begin{array}{l}0.051^{*} \\
(0.025)\end{array}$ & $\begin{array}{l}0.041^{+} \\
(0.021)\end{array}$ \\
\hline Mainland distance $\times$ placebo & $\begin{array}{c}0.005 \\
(0.083)\end{array}$ & $\begin{array}{c}0.019 \\
(0.023)\end{array}$ & $\begin{array}{c}0.016 \\
(0.019)\end{array}$ \\
\hline Mainland distance (PCA) & $\begin{array}{c}0.142^{*} \\
(0.058)\end{array}$ & $\begin{array}{l}-0.009 \\
(0.017)\end{array}$ & $\begin{array}{c}0.000 \\
(0.014)\end{array}$ \\
\hline Treatment & $\begin{array}{l}-0.016 \\
(0.157)\end{array}$ & $\begin{array}{l}-0.030 \\
(0.047)\end{array}$ & $\begin{array}{c}-0.014 \\
(0.038)\end{array}$ \\
\hline Placebo & $\begin{array}{c}-0.104 \\
(0.159)\end{array}$ & $\begin{array}{c}0.020 \\
(0.047)\end{array}$ & $\begin{array}{c}0.046 \\
(0.038)\end{array}$ \\
\hline Observations & 571 & 571 & 571 \\
\hline
\end{tabular}

Note: This table presents the heterogeneous treatment effects using a continuous measure of distance to mainlanders. The measure is based on the first principal component from the six mainland distance questions. Robust standard errors are in parentheses.

${ }^{+} p<0.1,{ }^{*} p<0.05,{ }^{* *} p<0.01$ (two-tailed test) 
Table A.5: Robustness: Controlling for Additional Covariates

\begin{tabular}{|c|c|c|c|c|c|c|c|c|c|c|c|c|}
\hline \multirow[b]{2}{*}{ Treatment effect by distance to mainlanders } & \multicolumn{4}{|c|}{ Overall Support for Democracy (PCA) } & \multicolumn{4}{|c|}{$\begin{array}{c}\% \text { Donated to Pro-Democracy } \\
\text { Organizations (from } 30 \mathrm{HKD} \\
\text { payment) }\end{array}$} & \multicolumn{4}{|c|}{$\begin{array}{c}\% \text { Donated to Pro-Democracy } \\
\text { Organizations (from } 500 \text { HKD } \\
\text { Lottery) }\end{array}$} \\
\hline & (1) & (2) & (3) & (4) & (5) & (6) & (7) & (8) & (9) & (10) & (11) & (12) \\
\hline Top $25 \%$ & $\begin{array}{l}0.840^{* *} \\
(0.247)\end{array}$ & $\begin{array}{l}0.944^{* *} \\
(0.247)\end{array}$ & $\begin{array}{l}1.010^{* *} \\
(0.246)\end{array}$ & $\begin{array}{l}1.037^{* *} \\
(0.259)\end{array}$ & $\begin{array}{l}0.194^{*} \\
(0.082)\end{array}$ & $\begin{array}{l}0.175^{*} \\
(0.083)\end{array}$ & $\begin{array}{l}0.262^{* *} \\
(0.082)\end{array}$ & $\begin{array}{l}0.241^{* *} \\
(0.090)\end{array}$ & $\begin{array}{c}0.153^{*} \\
(0.071)\end{array}$ & $\begin{array}{l}0.127^{+} \\
(0.073)\end{array}$ & $\begin{array}{l}0.210^{* *} \\
(0.070)\end{array}$ & $\begin{array}{l}0.208^{* *} \\
(0.075)\end{array}$ \\
\hline $50 \%$ to $75 \%$ & $\begin{array}{c}0.150 \\
(0.243)\end{array}$ & $\begin{array}{c}0.204 \\
(0.249)\end{array}$ & $\begin{array}{c}0.255 \\
(0.245)\end{array}$ & $\begin{array}{c}0.230 \\
(0.253)\end{array}$ & $\begin{array}{l}-0.065 \\
(0.079)\end{array}$ & $\begin{array}{c}-0.064 \\
(0.082)\end{array}$ & $\begin{array}{c}-0.080 \\
(0.080)\end{array}$ & $\begin{array}{l}-0.091 \\
(0.087)\end{array}$ & $\begin{array}{l}-0.040 \\
(0.065)\end{array}$ & $\begin{array}{c}-0.057 \\
(0.068)\end{array}$ & $\begin{array}{l}-0.076 \\
(0.064)\end{array}$ & $\begin{array}{c}-0.083 \\
(0.066)\end{array}$ \\
\hline $25 \%$ to $50 \%$ & $\begin{array}{l}-0.011 \\
(0.265)\end{array}$ & $\begin{array}{c}-0.081 \\
(0.281)\end{array}$ & $\begin{array}{l}-0.100 \\
(0.254)\end{array}$ & $\begin{array}{c}-0.048 \\
(0.250)\end{array}$ & $\begin{array}{c}-0.126^{+} \\
(0.074)\end{array}$ & $\begin{array}{c}-0.113 \\
(0.074)\end{array}$ & $\begin{array}{l}-0.161^{*} \\
(0.076)\end{array}$ & $\begin{array}{c}-0.152^{+} \\
(0.078)\end{array}$ & $\begin{array}{c}-0.067 \\
(0.062)\end{array}$ & $\begin{array}{c}-0.071 \\
(0.063)\end{array}$ & $\begin{array}{c}-0.115^{+} \\
(0.064)\end{array}$ & $\begin{array}{c}-0.103 \\
(0.065)\end{array}$ \\
\hline Bottom 25\% & $\begin{array}{l}-0.025 \\
(0.283)\end{array}$ & $\begin{array}{l}-0.092 \\
(0.275)\end{array}$ & $\begin{array}{l}-0.198 \\
(0.301)\end{array}$ & $\begin{array}{l}-0.098 \\
(0.296)\end{array}$ & $\begin{array}{l}-0.083 \\
(0.081)\end{array}$ & $\begin{array}{l}-0.095 \\
(0.078)\end{array}$ & $\begin{array}{c}-0.066 \\
(0.083)\end{array}$ & $\begin{array}{l}-0.096 \\
(0.086)\end{array}$ & $\begin{array}{c}-0.112^{+} \\
(0.065)\end{array}$ & $\begin{array}{l}-0.083 \\
(0.066)\end{array}$ & $\begin{array}{l}-0.076 \\
(0.068)\end{array}$ & $\begin{array}{c}-0.094 \\
(0.071)\end{array}$ \\
\hline Treatment $\times$ demographics & $\checkmark$ & & & $\checkmark$ & $\checkmark$ & & & $\checkmark$ & $\checkmark$ & & & $\checkmark$ \\
\hline Treatment $\times$ academic background & & $\checkmark$ & & $\checkmark$ & & $\checkmark$ & & $\checkmark$ & & $\checkmark$ & & $\checkmark$ \\
\hline Observations & 570 & 571 & 571 & 570 & 570 & 571 & 571 & 570 & 570 & 571 & 571 & 570 \\
\hline
\end{tabular}

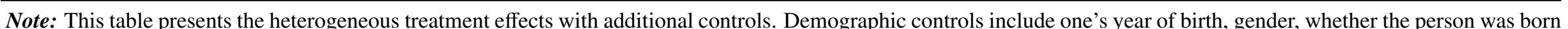

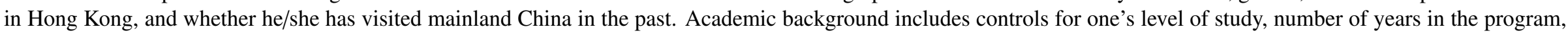
faculty affiliation, and cohort year. Family covariates include subjective evaluation of family socioeconomic status, mother's and father's education and places of birth.

${ }^{+} p<0.1,{ }^{*} p<0.05,{ }^{* *} p<0.01$ (two-tailed test) 


\section{Original Texts of the Treatment and Outcome Questions for Study 1}

\section{D.1 Treatment}

現時香港有許多來自中國内地的人士, 如果他們作為你的【男/女朋友】【親戚】【老 師】【鄰居】【室友】【好友】, 你會感到?

1. 非常不介意

2. 不介意

3. 有點不介意

4. 有點介意

5. 介意

6. 非常介意

\section{D.2 Placebo}

現時香港有許多殘疾人士, 如果他們作為你的【男/女朋友】【親戚】【老師】【鄰居】 【室友】【好友】, 你會感到?

1. 非常不介意

2. 不介意

3. 有點不介意

4. 有點介意

5. 介意

6. 非常介意

\section{D.3 Democratic Attitudes}

Item \# 1 你對於以下陳述有甚麼看法? 雖然民主政治有缺陷, 但比任何一個政制為佳

1. 非常不同意

2. 比較不同意

3. 比較同意

4. 非常同意 
Item \# 2 你對於以下陳述有甚麼看法? 為了實現民主, 我願意承受超過五年的經濟衰 退、失業、和生活質量下降

1. 非常不同意

2. 比較不同意

3. 比較同意

4. 非常同意

Item \# 3 你對於以下陳述有甚麼看法? 如果條件允許, 我願意停學一年, 把時間用於爭 取民主

1. 非常不同意

2. 比較不同意

3. 比較同意

4. 非常同意

Item \# 4 你對於以下陳述有甚麼看法? 為了爭取民主, 我願意在工作場所宣傳我的理 念, 就算這有可能會令我被解雇

1. 非常不同意

2. 比較不同意

3. 比較同意

4. 非常同意

Item \# 5 你對於以下陳述有甚麼看法? 必要情況下, 可以用武力對付發表反對民主言論 的人

1. 非常不同意

2. 比較不同意

3. 比較同意

4. 非常同意

Item \# 6 你對於以下陳述有甚麼看法? 只要目的是爭取民主, 我支持通過散佈謠言和假 新聞來打擊當局

1. 非常不同意

2. 比較不同意

3. 比較同意

4. 非常同意 


\section{E Additional Information \& Robustness Checks for Study 2}

\section{E.1 Original Treatment Texts and English Translation}

[Outgroup Threat + ] 在全球化浪潮下, 人口流動比以往便捷及頻繁。各種形式的人口 跨國和跨境流動, 産生了經濟效益, 但也可能給當地帶新的問題。我們想知道你對香港 的人口流動模式的了解情況。你估計, 在 2018 年有多少内地訪客通過旅遊簽證來港? 請 在下面填入你覺得最有可能的數字, 以萬為單位。我們只想知道你個人的估計, 無需查 閲其他資料。In a time of globalization, the movement of people has become more convenient and frequent. Different forms of cross-regional immigration can create economic benefits but may also produce new problems for the destination. We would like to learn a bit about your view on population movements concerning Hong Kong: According to your own estimate, how many mainland Chinese visited Hong Kong on tourist visas in 2018? Please input below the figure that you think is most likely. We just want to know your personal estimate. There is no need to search for additional information.

你的答案是Your estimate is : [X]

(Next Page)

對於 2018 年内地訪客數字, 剛才您的答案是 $\mathrm{X}$ 。根據旅遊發展局的數據, 2018年從内地 來港的人數為 5103 萬。為香港常住人口（約745萬）的7倍。值得一提的是, 許多水客, 内 地炒房者, 以及早年的雙非來港生子, 也都是通過一簽多行的旅遊簽證來港。Your answer is X. According to data from the Tourism Bureau, the actual number is 51.03 million, which is about 7 times the size of the permanent population in Hong Kong (about 7.45 million). It is also worth noting that many parallel traders, property speculators, and those who came for birth tourism in the earlier days all came to Hong Kong on tourist visas.

[Outgroup Threat -] 在全球化浪潮下, 人口流動比以往便捷及頻繁。各種形式的人口跨 國和跨境流動, 産生了經濟效益, 但也可能給當地帶新的問題。我們想知道你對香港的 人口流動模式的了解情況。你認為, 從2002年到2018年, 内地新移民(持單程證來港)的人 數變化情況是怎麼樣的? 請選擇你認為最有可能的個百分比變化(percentage change)。我 們只想知道你個人的估計, 無需查閲其他資料。In a time of globalization, the movement of people has become more convenient and frequent. Different forms of cross-regional immigration can create economic benefits but may also produce new problems for the destination. We would like to learn a bit about your view on population movements concerning Hong Kong: According to your own estimate, between 2002 and 2018, how has the number of new mainland immigrants (individuals coming with one-way permits) changed? Please choose the most likely percentage change figure. We just want to know your personal estimate. There is no need to search for additional information.

你的答案是Your answer is : [X]

(Next Page)

對於 2002 年到 2018 年單程證來港人數變化情況, 剛才您的答案是X。根據統計處數 據，2018新移民來港人數約為4.2萬人, 比起 2002 年(約 4.53 萬人)減少了約 $6 \%$ 。根據香港大 學社會學系最近的一份研究顯示, 新移民的對本地工資和就業市場影響十分有限, 且他 們往往有很强的意願去學習和融入本地文化。Your estimate is X. According to data from the 
Statistics Bureau, the number of new mainland immigrants in 2018 was about 42 thousand, which is about $6 \%$ less than the figure in 2002 (45.3 thousand). According to a recent study by HKU, new mainland immigrants have limited impact on the local wage and labor market, and they have a strong willingness to learn and integrate into the local culture.

Figure A.10: Distribution of Respondents' Estimates and the Answer Provided
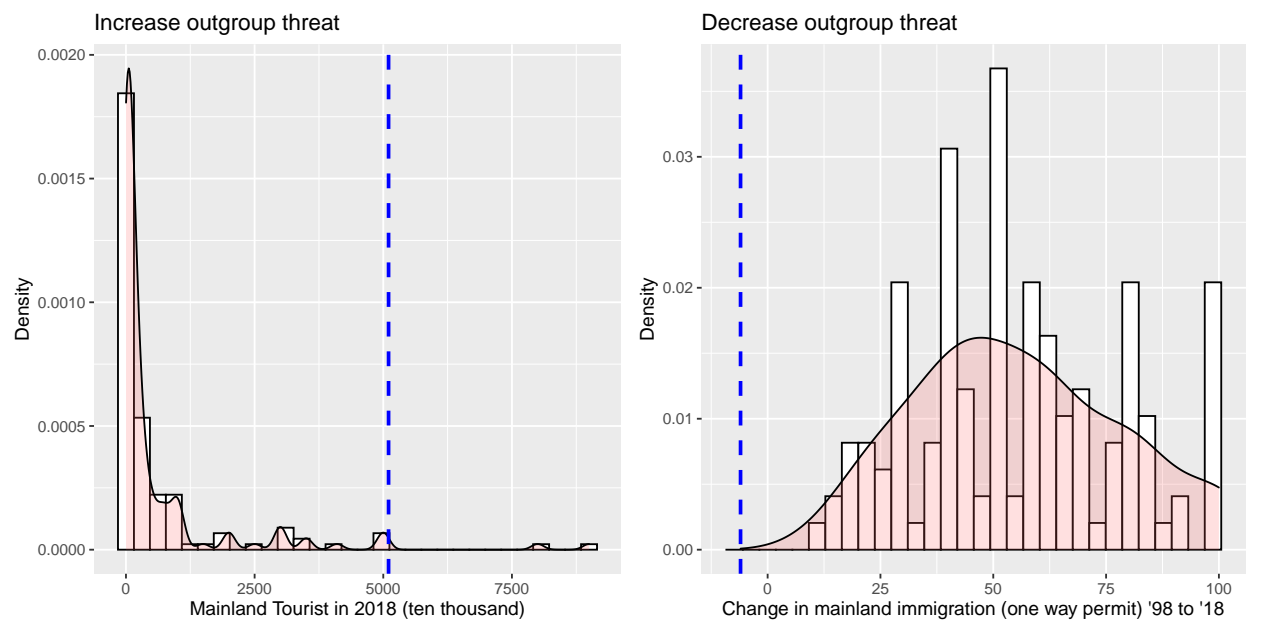

Note: This figure presents the distribution of subjects' answers to the two treatment questions in Study 2 relative to the actual answer provided. The histogram represents the distribution of subjects' answers and the blue dashed line represents the value of the answer we provided. We can see that the actual answers are typically more extreme than what the beliefs of the vast majority of the subjects.

Table A.6: Numerical Results for Experimental Study 2

\begin{tabular}{|c|c|c|c|c|}
\hline & \multicolumn{2}{|c|}{$\begin{array}{l}\text { DV: Subjective } \\
\text { Distance to } \\
\text { Mainland } \\
\text { Chinese (PCA) }\end{array}$} & \multicolumn{2}{|c|}{$\begin{array}{l}\text { DV: Overall } \\
\text { Support for } \\
\text { Democracy } \\
\text { (PCA) }\end{array}$} \\
\hline & (1) & (2) & (3) & (4) \\
\hline Increase outgroup threat (mainland tourist treatment) & $\begin{array}{l}0.718^{* *} \\
(0.234)\end{array}$ & $\begin{array}{l}0.683^{* *} \\
(0.234)\end{array}$ & $\begin{array}{l}0.420^{*} \\
(0.189)\end{array}$ & $\begin{array}{l}0.425^{*} \\
(0.196)\end{array}$ \\
\hline Decrease outgroup threat (one-way permit holder treatment) & $\begin{array}{c}0.069 \\
(0.243)\end{array}$ & $\begin{array}{c}0.204 \\
(0.255)\end{array}$ & $\begin{array}{c}0.097 \\
(0.203)\end{array}$ & $\begin{array}{c}0.127 \\
(0.211)\end{array}$ \\
\hline $\begin{array}{l}\text { Covariates } \\
\text { Observations }\end{array}$ & 379 & $\begin{array}{c}\checkmark \\
379\end{array}$ & 379 & $\begin{array}{c}\checkmark \\
379\end{array}$ \\
\hline
\end{tabular}

Note: This table presents the numerical results for the estimated effects of the two treatments in the second experimental study (visualized in Figure 5). Additional covariates include gender, birth year, number of years in the program, residing district fixed effects, faculty/school fixed effects, and subjective evaluation of family socioeconomic status. Robust standard errors are in parentheses.

${ }^{+} p<0.1,{ }^{*} p<0.05,{ }^{* *} p<0.01$ (two-tailed test) 
Table A.7: Robustness Check: Excluding Repeated Takers from Study 1

\begin{tabular}{|c|c|c|c|c|}
\hline & \multicolumn{2}{|c|}{$\begin{array}{l}\text { DV: Subjective } \\
\text { Distance to } \\
\text { Mainland } \\
\text { Chinese (PCA) }\end{array}$} & \multicolumn{2}{|c|}{$\begin{array}{l}\text { DV: Overall } \\
\text { Support for } \\
\text { Democracy } \\
\text { (PCA) }\end{array}$} \\
\hline & (1) & $(2)$ & (3) & (4) \\
\hline Increase outgroup threat (mainland tourist treatment) & $\begin{array}{l}0.718^{*} \\
(0.281)\end{array}$ & $\begin{array}{l}0.650^{*} \\
(0.281)\end{array}$ & $\begin{array}{l}0.400^{+} \\
(0.227)\end{array}$ & $\begin{array}{l}0.451^{+} \\
(0.239)\end{array}$ \\
\hline Decrease outgroup threat (one-way permit holder treatment) & $\begin{array}{c}0.275 \\
(0.294)\end{array}$ & $\begin{array}{c}0.466 \\
(0.309)\end{array}$ & $\begin{array}{c}0.146 \\
(0.245)\end{array}$ & $\begin{array}{c}0.295 \\
(0.258)\end{array}$ \\
\hline $\begin{array}{l}\text { Covariates } \\
\text { Observations }\end{array}$ & 282 & $\begin{array}{c}\checkmark \\
282\end{array}$ & 282 & $\begin{array}{c}\checkmark \\
282\end{array}$ \\
\hline
\end{tabular}

Note: This table presents the numerical results for the estimated effects of the four treatments in the second experimental study, excluding subjects who also participated in Study 1. Additional covariates include gender, birth year, number of years in the program, residing district fixed effects, faculty/school fixed effects, and subjective evaluation of family socioeconomic status. Robust standard errors are in parentheses.

${ }^{+} p<0.1,{ }^{*} p<0.05,{ }^{* *} p<0.01$ (two-tailed test)

\section{F Additional Information for the Observational Studies}

\section{F.1 Data on the Number of Medicine Shops Over Time}

We put together a list of local medicine sellers for 2007 and 2017 using both archived information at online yellow page websites and the registration records from the Office of the Government Chief Information Officer. By law, sellers of any kinds of medicines in Hong Kong, including over-thecounter prescriptions, must obtain a license from the Drug Office of the Department of Health. The raw seller list we obtain includes supermarkets, convenience stores and other establishments that are not tourism-oriented. One unique fact about shops that cater primarily to parallel traders and tourists is that they typically include the Chinese character for medicine (藥) in their names for easy identification (e.g. 藥行、藥妝、藥莊). To select only those establishments, we obtained a subset of sellers whose names contain that character. The addresses from the subset is inputted to Google's Geo-coding API to obtain their geo-locations. We then aggregate the number of medicine shops in business by district and compute the rate of change in each district from 2007 to 2017.

\section{F.2 Calculating Closeness to Checkpoints (via Public Transit)}

We use Google's Distance Matrix API to calculate the public transport travel time at 11 a.m. on a Wednesday from Lo Wu Station to the polling station(s) of each of the district council constituencies. Since travel time from Lo Wu is highly collinear with that from Lok Ma Chau (as the two checkpoints are adjacent terminals of the same railway line), we choose to focus on Lo Wu (the busier station) without loss of generality. If there is more than one polling station within a district council, we take the arithmetic mean of the transit time to all polling stations produce the district council constituency travel time. We use the inverse of the (average) district council travel time 
$\left(\frac{1}{\text { travel time }}\right)$ as the main closeness measure. For the survey analysis, we first aggregate travel time to district-level (by averaging across all district councils within a district) and compute a similar inverse travel time variable at the district level.

\section{F.3 Data on Public Opinion and Election Results}

The survey data we use come from the Hong Kong Election Study (HKES), which include a series of representative surveys fielded between 2015 and 2017. ${ }^{33}$ HKES provide geographical information of respondents to the district level (i.e. each respondent was coded to belong to one of the 18 districts.), which enables us to incorporate district-level characteristics into the analysis. We use four survey questions to measure respondents' inter-group attitude and support for democracy. The detailed wordings of these questions are shown in Table A.8.

Table A.8: Original Question Texts from the HKES

\begin{tabular}{|c|c|c|c|}
\hline Question Text (English) & $\begin{array}{l}\text { Question Text (Can- } \\
\text { tonese) }\end{array}$ & Years & Choices \\
\hline $\begin{array}{l}\text { "Hong Kong has too } \\
\text { many immigrants } \\
\text { coming from Mainland } \\
\text { China." }\end{array}$ & $\begin{array}{l}\text { 「香港有太多來自中 } \\
\text { 國大陸的新移民。」 }\end{array}$ & 2015,2016 & $\begin{array}{l}\text { Strongly disagree (1) to } \\
\text { strongly agree (5) (kept the } \\
\text { original scale) }\end{array}$ \\
\hline $\begin{array}{l}\text { "Generally speaking, } \\
\text { do you think of yourself } \\
\text { as:" }\end{array}$ & $\begin{array}{l}\text { 「總括來説, 您認為 } \\
\text { 自己是 : 」 }\end{array}$ & $\begin{array}{l}2015,2016, \\
2017\end{array}$ & $\begin{array}{l}\text { Chinese (1), Chinese, but } \\
\text { also Hong Konger (2), Hong } \\
\text { Konger, but also Chinese (3), } \\
\text { Hong Konger (4) (kept the } \\
\text { original scale) }\end{array}$ \\
\hline $\begin{array}{l}\text { "In your opinion how } \\
\text { much of a democracy is } \\
\text { Hong Kong today?" }\end{array}$ & $\begin{array}{l}\text { 「一般來説，您覺 } \\
\text { 得目前香港有幾民主 } \\
\text { 呢?」」 }\end{array}$ & 2016,2017 & $\begin{array}{l}\text { Not a democracy (1), a } \\
\text { democracy with major prob- } \\
\text { lems (2), a democracy but } \\
\text { with minor problems (3), a } \\
\text { full democracy (4) (kept the } \\
\text { original scale) }\end{array}$ \\
\hline
\end{tabular}

For our analysis of the election data, we obtain Legislative Council (LegCo) election results from the Electoral Affairs Commission of Hong Kong (www. eac.gov.hk). Hong Kong's Legislative Council (LegCo) elections were organized along two groups of seats: geographical constituency seats elected directly by voters and functional constituency seats elected by corporations and individuals representing different interest sectors. ${ }^{34}$ Our analysis focuses only on the geographical constituency seats, which are generally more competitive and can be easily matched to our location-based mainland exposure measure. Hong Kong has a total of 5 multi-member geographical constituencies, each electing 5 to 9 members by proportional representation. Each

\footnotetext{
${ }^{33}$ The survey data are publicly available at https: //hkelectionstudy .org/.

${ }^{34}$ Since 2012, 5 functional constituency seats were elected in a multi-member territory-wide at-large constituency by voters who are otherwise ineligible to vote for the other 30 'traditional' functional constituency seats. Our analysis focuses on the geographical constituency seats.
} 
geographical constituency is partitioned into 18 districts, which are further partitioned into 452 district council constituencies. The LegCo election results that we obtain are disaggregated at the district council level.

The election data contain the full list of individuals who have run in the last four LegCo elections. Due to the nature of the Hong Kong electoral system (Hare quota with small district magnitudes), it is common for the two major political camps to field multiple candidates in multiple lists, with some of them not declaring a political affiliation. While successful candidates can be coded by their voting pattern in the legislature, there were many unsuccessful candidates who were clearly supported by one of the political camps. In light of these challenges, we classify their political stance (pro-regime vs. pro-democracy) using the following system. Firstly, if a candidate belongs to a pro-regime or pro-democracy political party, we will code their political affiliation as such. This is defined by whether a majority of its elected representatives ${ }^{35}$ had ever cast a no vote on the government budget (Appropriation Bill) or against the symbolic 'motion of thanks' on the policy address. For 'independents' who were successfully elected, we code their political camp by this rule as well. However, for candidates whose election bid was unsuccessful and who do not declare a political affiliation, we first examine whether they had (or will) belong to a pro-establishment or pro-democracy party. If that is unsuccessful, we use information from Hong Kong's newspaper of record, the South China Morning Post. Our research assistant coded a candidate as being pro-regime or pro-democracy if the Post ever described the candidate as pro-regime or pro-democracy.

In Table A.9, we list all political parties winning at least one directly elected seats between 2004 and 2016, and we also list whether a majority of its legislators voted against the appropriation bill (budget) or the motion of thanks on the policy address, between 2004 and 2017. Note that the two representatives running on the AllinHK alliance (\#) were barred from serving in the legislature before the first meeting due to the oath taking saga; as such, they did not vote on any bills. We coded them as part of the opposition pro-democracy camp as they were disqualified by a lawsuit brought forth by the government. In the four columns representing the four elections, the abbreviations' meanings are as follows: 'W' - ran and won at least one seat; 'F' - ran, did not win any directly elected GC seats, but won at least one seat overall; 'R' - ran, but did not win any seats.

\footnotetext{
${ }^{35}$ For simplicity, we ignore party change during a legislative session and only focus on representatives elected from the directly elected seats (geographical constituencies)
} 
Table A.9: List of political parties winning at least one GC seat from 2004 to 2016

\begin{tabular}{|c|c|c|c|c|c|c|c|c|c|}
\hline Party Name (English) & $\begin{array}{l}\text { Party Abbre- } \\
\text { viation }\end{array}$ & Camp & 04 & 08 & 12 & 16 & Predecessor & $\begin{array}{l}\text { Voted against appro- } \\
\text { priation }\end{array}$ & $\begin{array}{l}\text { Voted against 'mo- } \\
\text { tion of thanks' }\end{array}$ \\
\hline $\begin{array}{l}\text { Democratic Alliance for the Better- } \\
\text { ment of Hong Kong }\end{array}$ & DAB & Regime & $\mathrm{W}$ & $\mathrm{W}$ & $\mathrm{W}$ & $\mathrm{W}$ & & & \\
\hline Democratic Party & $\mathrm{DP}$ & Democracy & $\mathrm{W}$ & $\mathrm{W}$ & $\mathrm{W}$ & $\mathrm{W}$ & & $09,10,11,13,15,17$ & $\begin{array}{l}05,09,10,13,14,15, \\
16,17\end{array}$ \\
\hline Article 45 Concern Group & 45 Concern & Democracy & $\mathrm{W}$ & & & & & & 05,06 \\
\hline Liberal Party & Liberal & Regime & $\mathrm{W}$ & $\mathrm{F}$ & $\mathrm{W}$ & $\mathrm{F}$ & & & \\
\hline $\begin{array}{l}\text { Hong Kong Federation of Trade } \\
\text { Unions }\end{array}$ & FTU & Regime & $\mathrm{W}$ & $\mathrm{W}$ & $\mathrm{W}$ & $\mathrm{W}$ & & & \\
\hline The Frontier & Frontier & Democracy & $\mathrm{W}$ & $\mathrm{W}$ & & & & $06,09,10,11$ & $05,07,08,09,10$ \\
\hline $\begin{array}{l}\text { Hong Kong Association for } \\
\text { Democracy and People's Liveli- } \\
\text { hood }\end{array}$ & APDL & Democracy & $\mathrm{W}$ & W & W & $\mathrm{R}$ & & $\begin{array}{l}09,10,11,12,13,15 \\
16\end{array}$ & $\begin{array}{l}05,06,08,09,10,11, \\
13,14,15,16\end{array}$ \\
\hline $\begin{array}{l}\text { Hong Kong Confederation of Trade } \\
\text { Unions }\end{array}$ & CTU & Democracy & $\mathrm{W}$ & $\mathrm{W}$ & & & & $05,09,10,11,12$ & $05,06,07,09,10,11$ \\
\hline April Fifth Action & April Fifth & Democracy & $\mathrm{W}$ & & & & & $05,06,08$ & 05,06 \\
\hline $\begin{array}{l}\text { Neighbourhood and Worker's Ser- } \\
\text { vice Centre }\end{array}$ & NWSC & Democracy & $\mathrm{W}$ & $\mathrm{W}$ & $\mathrm{W}$ & $\mathrm{F}$ & & $\begin{array}{l}06,07,08,09,10,12 \\
13,15,16\end{array}$ & $\begin{array}{l}05,06,07,09,10,11, \\
13,14,15,16\end{array}$ \\
\hline Civic Party & Civic & Democracy & & $\mathrm{W}$ & $\mathrm{W}$ & $\mathrm{W}$ & 45 Concern & $\begin{array}{l}09,10,11,12,13,14 \\
15,16,17\end{array}$ & $\begin{array}{l}09,10,11,13,14,15, \\
16,17\end{array}$ \\
\hline League of Social Democrats & LSD & Democracy & & $\mathrm{W}$ & $\mathrm{W}$ & $\mathrm{W}$ & April Fifth & $\begin{array}{l}09,10,11,12,15,16 \\
17\end{array}$ & $\begin{array}{l}08,09,10,11,13,14, \\
15,16,17\end{array}$ \\
\hline Civic Act-up & $\mathrm{CA}$ & Democracy & & $\mathrm{W}$ & $\mathrm{W}$ & $\mathrm{R}$ & & $\begin{array}{l}09,10,11,12,13,15 \\
16\end{array}$ & $\begin{array}{l}08,09,10,11,13,14, \\
15,16\end{array}$ \\
\hline New People's Party & NPP & Regime & & & $\mathrm{W}$ & $\mathrm{W}$ & & & \\
\hline Kowloon West New Dynamic & KWND & Regime & & & $\mathrm{W}$ & & & & \\
\hline Labour Party & Lab & Democracy & & & $\mathrm{W}$ & $\mathrm{W}$ & & $13,15,16,17$ & $13,14,15,16,17$ \\
\hline People Power & $\mathrm{PP}$ & Democracy & & & $\mathrm{W}$ & $\mathrm{W}$ & LSD (partly) & $15,16,17$ & $13,14,15,16,17$ \\
\hline Neo Democrats & $\mathrm{ND}$ & Democracy & & & $\mathrm{W}$ & $\mathrm{R}$ & Dem (partly) & $13,14,15,16$ & $13,14,15,16$ \\
\hline $\begin{array}{l}\text { Business and Professionals Al- } \\
\text { liance for Hong Kong }\end{array}$ & BPA & Regime & & & & $\mathrm{W}$ & $\begin{array}{l}\text { KWND } \\
\text { (partly) }\end{array}$ & & \\
\hline ALLinHK / Youngspiration & ALL & Democracy & & & & $\mathrm{W}$ & & \# & $\#$ \\
\hline $\begin{array}{l}\text { Civic Passion-Proletariat Political } \\
\text { Institute-Hong Kong Resurgence } \\
\text { Order }\end{array}$ & $\mathrm{CP}$ & Democracy & & & & $\mathrm{W}$ & & 17 & 17 \\
\hline Demosistō & DTO & Democracy & & & & $\mathrm{W}$ & & 17 & 17 \\
\hline Democracy Groundwork & DGR & Democracy & & & & $\mathrm{W}$ & & 17 & 17 \\
\hline
\end{tabular}




\section{F.4 Results}

Table A.10: Residential Proximity to Lo Wu and Social \& Political Attitudes

\begin{tabular}{|c|c|c|c|c|c|}
\hline & $\begin{array}{c}\begin{array}{c}\text { Percentage } \\
\text { change in }\end{array} \\
\text { medicine shops, } \\
17-07\end{array}$ & $\begin{array}{l}\text { HK has too } \\
\text { many } \\
\text { immigrants } \\
\text { from mainland }\end{array}$ & $\begin{array}{c}\text { Identify as } \\
\text { Hong Konger } \\
\text { (as opposed to } \\
\text { Chinese) }\end{array}$ & $\begin{array}{c}\text { Democracy is } \\
\text { suitable for HK } \\
\text { (higher value = } \\
\text { more } \\
\text { agreement) }\end{array}$ & $\begin{array}{c}\text { How } \\
\text { democratic is } \\
\text { HK (higher } \\
\text { value = more } \\
\text { democratic)? }\end{array}$ \\
\hline & (1) & (2) & (3) & (4) & (5) \\
\hline Closeness to Lo $\mathrm{Wu}$ & $\begin{array}{l}0.554^{* *} \\
(0.115)\end{array}$ & $\begin{array}{l}0.090^{* *} \\
(0.030)\end{array}$ & $\begin{array}{l}0.090^{* *} \\
(0.033)\end{array}$ & $\begin{array}{l}0.096^{*} \\
(0.044)\end{array}$ & $\begin{array}{c}-0.145^{* *} \\
(0.048)\end{array}$ \\
\hline Waves covered & & 15,16 & $15,16,17$ & $15,16,17$ & 16,17 \\
\hline Covariates & & $\checkmark$ & $\checkmark$ & $\checkmark$ & $\checkmark$ \\
\hline Observations & 18 & 8204 & 11761 & 11613 & 9491 \\
\hline
\end{tabular}

Note: This table shows how geographical closeness to mainland China is associated with the post-2008 change in Hong Kong's commercial landscape and public attitudes toward mainland Chinese. The public opinion data are from Hong Kong Election Study. Closeness is calculated by the inverse of travel time to the Lo Wu checkpoint. In the first Column, we estimate: \% change in \# of medicine shops ${ }_{d}=\delta$ Closeness to Lo $\mathrm{Wu}_{d}+\eta_{d}+\epsilon_{i d}$, where $d$ denotes one of Hong Kong's 18 districts and $\eta$ represents one of the three main regions (Hong Kong Island, Kowloon, and New Territories). For

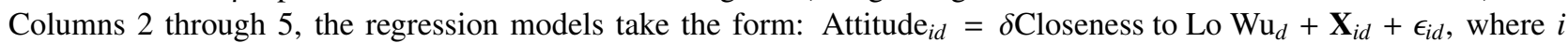
indexes individual respondent and $d$ denotes the district. The following variables are included in $\mathbf{X}$ : survey wave fixed effects, age, gender, college education, income level, and closeness to HK airport. Robust standard errors clustered at the survey-constituency level are in parentheses.

${ }^{+} p<0.1,{ }^{*} p<0.05,{ }^{* *} p<0.01$ (two-tailed test) 
Table A.11: The Effect of Closeness to Checkpoints on Pro-Regime Candidates' Vote Share, 2004-2016

\begin{tabular}{lcccc}
\hline & \multicolumn{4}{c}{ DV: Pro-Regime Party Vote Margin } \\
\cline { 2 - 5 } & $(1)$ & $(2)$ & $(3)$ & $(4)$ \\
\hline Closeness to Lo Wu (1/travel time) & $0.953^{* *}$ & $0.859^{* *}$ & -0.501 & -1.248 \\
& $(0.319)$ & $(0.318)$ & $(0.579)$ & $(0.939)$ \\
$2008 \times$ Closeness to Lo Wu (1/travel time) & -0.201 & -0.221 & -0.254 & -0.306 \\
& $(0.263)$ & $(0.252)$ & $(0.247)$ & $(0.232)$ \\
$2012 \times$ Closeness to Lo Wu (1/travel time) & $-1.038^{* *}$ & $-1.072^{* *}$ & $-1.176^{* *}$ & $-1.392^{* *}$ \\
& $(0.323)$ & $(0.305)$ & $(0.310)$ & $(0.374)$ \\
$2016 \times$ Closeness to Lo Wu (1/travel time) & $-2.104^{* *}$ & $-2.133^{* *}$ & $-2.259^{* *}$ & $-2.499^{* *}$ \\
& $(0.451)$ & $(0.431)$ & $(0.477)$ & $(0.502)$ \\
\hline Geographic constituency FE & $\checkmark$ & $\checkmark$ & & \\
District FE & & & $\checkmark$ & \\
District council FE & & & & $\checkmark$ \\
Socioeconomic controls & & $\checkmark$ & $\checkmark$ & $\checkmark$ \\
Observations & 2337 & 2337 & 2337 & 2336 \\
\hline
\end{tabular}

Note: This table presents the results on the relationship between closeness to Lo $\mathrm{Wu}$ and pro-regime candidates' vote share in the last four Legislative Council elections $(2004,2008$, 2012, 2016). Closeness is calculated by the inverse of the average travel time (on public transportation) from Lo Wu to polling stations within each district. The regression models we estimate takes the form: Pro-regime vote share ${ }_{c t g}=\delta$ Closeness to Lo $\mathrm{Wu}_{c} \times \mathrm{Year}_{t}+$ $\gamma$ Closeness to Lo $\mathrm{Wu}_{c}+\mathbf{X}_{c t g}+\tau_{t}+\eta_{g}+\epsilon_{c t g}$, where $i$ represents district councils, t represents year, and $g$ represents geographical constituencies or districts (larger territorial units encompassing multiple district councils). The following variables are controlled for in all regressions but not shown: district fixed effects, median income, \% of public housing, \% of private housing, \% of Cantonese speakers, and \% of college educated. The control variables are based on the 2016 Population By-census disaggregated at the district council constituency level (publicly available at https://www . bycensus2016.gov.hk/en/). Robust standard errors clustered at the constituency level are in parentheses.

${ }^{+} p<0.1,{ }^{*} p<0.05,{ }^{* *} p<0.01$ (two-tailed test) 
Figure A.11: Estimated Association between Closeness to Lo Wu on and Pro-Regime Candidates' Vote Share in Legislative Council Elections, 2004-2016

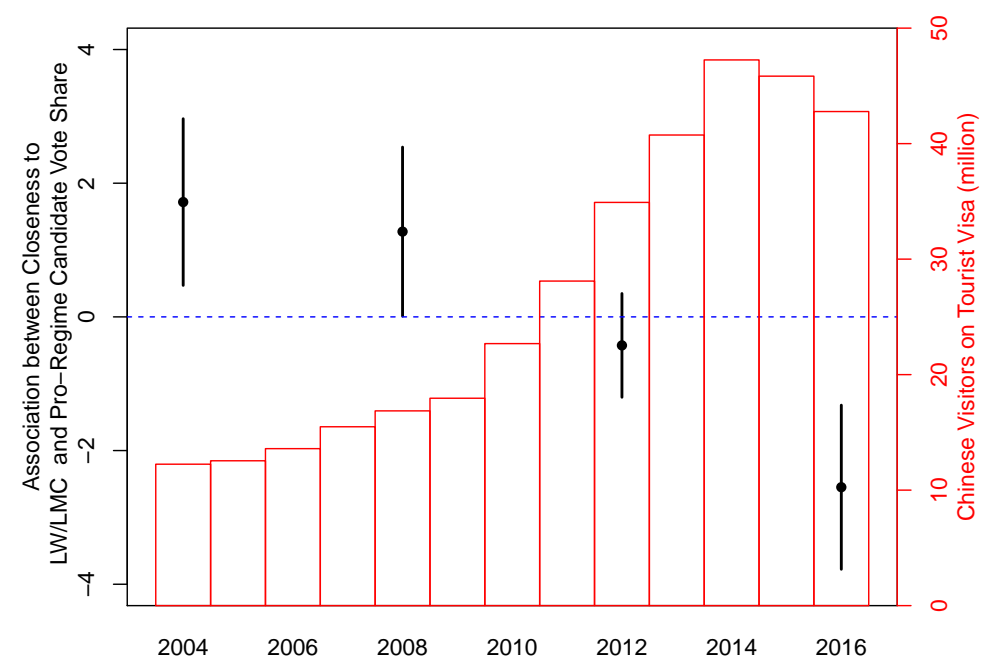

Note: This figure presents the estimated relationship between closeness to Lo Wu (measured by $1 /$ travel time on public transportation) and pro-regime candidates' vote share for the last four Legislative Council elections. The vertical lines indicate $95 \%$ confidence intervals. The red bars indicate the number of mainland visitors each year. For the numerical results, see Column 2 of Table A.11. LW = Lo Wu; LMC = Lok Ma Chau 